\title{
The Economic Impacts of Noxious Facilities on Wages and Property Values: An Exploratory Analysis
}

by L.A. Nieves, A.C. Hemphill, and D.E. Clark

Economics and Law Section,

Environmental Assessment and Information Sciences Division,

Argonne National Laboratory, 9700 South Cass Avenue, Argonne, Illinois 60439

May 1991 (printed February 1992)

Work sponsorf by United States Department of Energy, Office of Civilian Radioactive Waste Management 


\section{CONTENTS}

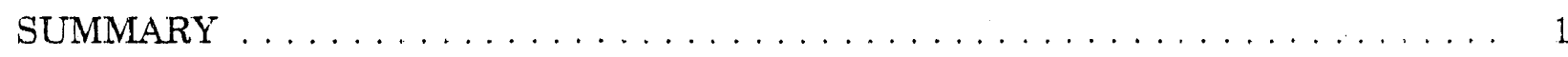

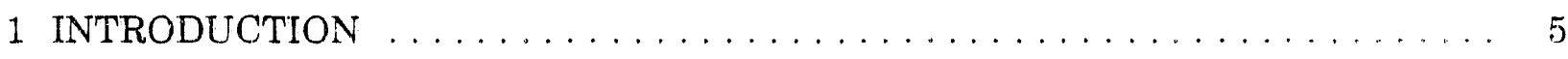

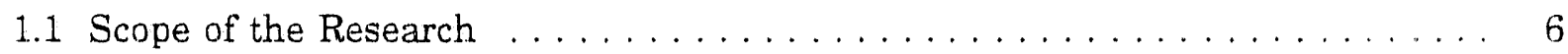

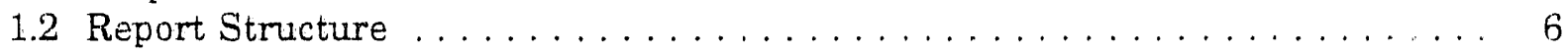

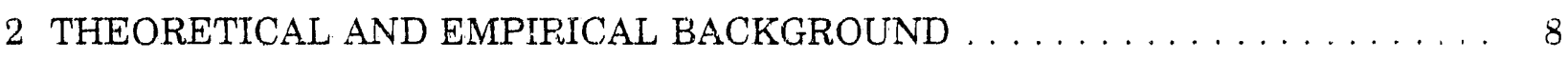

2.1 Hedonic Methods Applied to Amenity Valuation . . . . . . . . . . . . 8

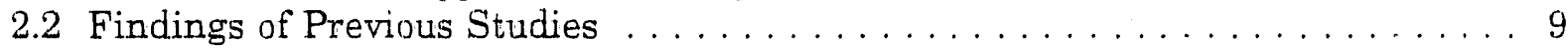

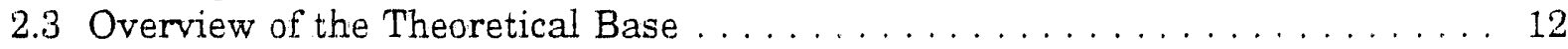

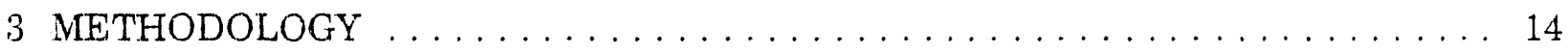

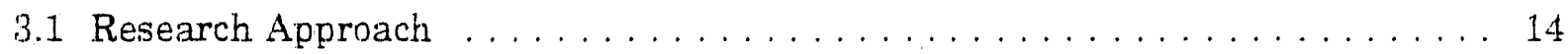

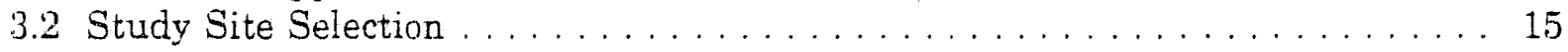

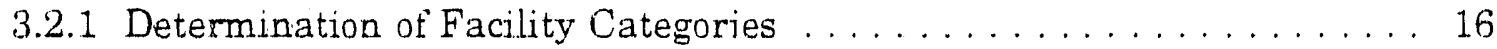

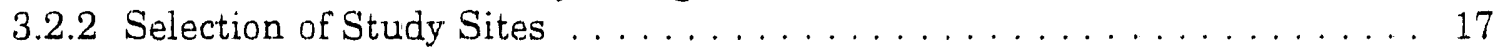

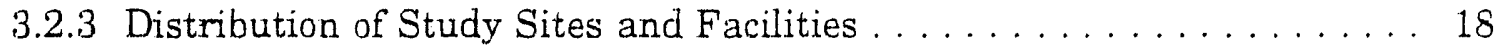

3.3 Data Set Development . . . . . . . . . . . . . . . . . . . . . . . . 19

3.3.1 Wage and Property Market Data . . . . . . . . . . . . . . . . . 21

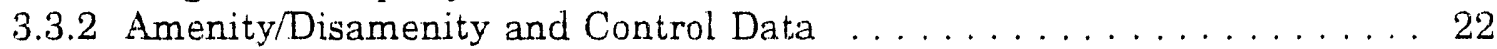

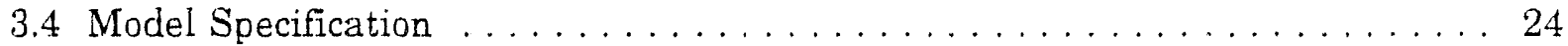

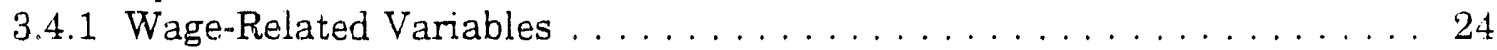

3.4.2 Housing-Related Variables . . . . . . . . . . . . . . . . . . 25

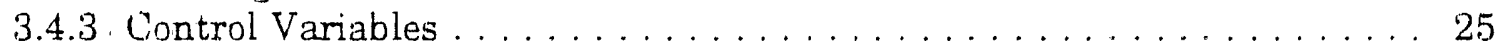

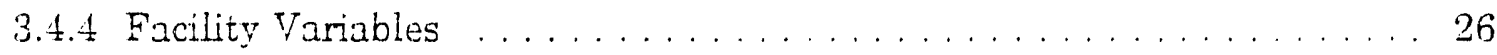

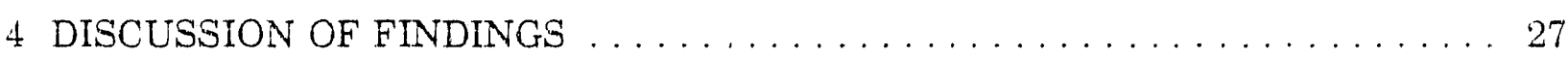

4.1 B.rkground Analysis . . . . . . . . . . . . . . . . . . 27

4.1.1 Comparison of Sites with and without Noxious Facilities . . . . . . . . 27

4.1 .2 Comparison of Renters and Home Owners . . . . . . . . . . . . . 29

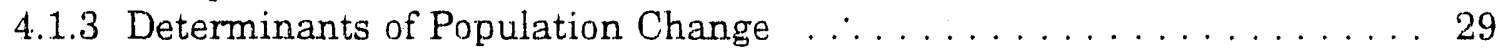

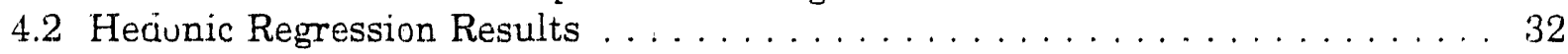

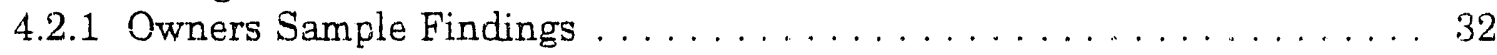

4.2 .2 Renters Sample Findings . . . . . . . . . . . . . . . . . 37

4.2.3 Comparison of Estimates for Selected Control and Facility Variables . . 42

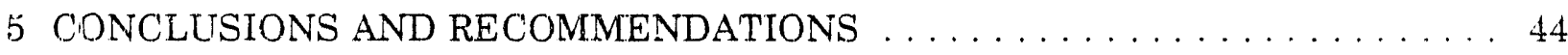

REFERENCES $\ldots \ldots \ldots \ldots \ldots \ldots \ldots \ldots \ldots \ldots \ldots \ldots \ldots \ldots$

APPENDIX A: Study Site Sample ....................... 49

APPENDIX B: Documentation of PUMS Variable Modifications . . . . . . . . 51 


\section{CONTENTS (Cont'd)}

APPENDIX C: County and City Data Book Variables . . . . . . . . . . . . . 59

APPENDLX D: Facility Information Sources . . . . . . . . . . . . . 61

\section{TABLES}

1 Number of Study Sites in Each of Four Census Regions . . . . . . . . . . . 19

2 Number of Noxious Facilities in All of the Study Sites . . . . . . . . . . 20

3 Number of Noxious Facilities in Each of Four Census Regions . . . . . . . . . 20

4 Comparison of Variable Means for Sites with and without Noxious Facilities . . . . . . . . . . . . . . . . . . . . . . . . . . 28

5 Personal Variable Means for Owners and Renters . . . . . . . . . . . . . 30

6 Estimated Coefficients for Population Change Models . . . . . . . . . . 31

7 Comparison of Facility Measures for Owaers Sample: Property Value Impacts . . 33

8 Comparison of Facility Measures for Owners Sample: Wage Impacts . . . . . . 36

9 Comparison of Facility Measures for Renters Sample: Property Value Impacts . . 38

10 Comparison of Facility Measures for Renters Sample: Wage Impacts . . . . . 40

11 Comparison of Amenity Variables in Facility Dummy Model Specification . . . . 43

B.1 Person Record Variable Modifications . . . . . . . . . . . . . . . 51

B.2 Housing Record Variable Modifications . . . . . . . . . . . . . 55 


\title{
THE ECONOMIC IMPACTS OF NOXIOUS FACILITIES ON WAGES AND PROPERTY VALUES: AN EXPLORATORY ANALYSIS
}

by

\author{
L.A. Nieves, R.C. Hemphill, and D.E. Clark
}

SUMMARY

Recent assessments of socioeconomic impacts resulting from the location of potentially hazardous facilities have concentrated on the issue of negative public perceptions and their resulting economic consequences. This report presents an analysis designed to answer the question: Can economic impacts resulting from negative perceptions of "noxious facilities" be identified and measured? To identify the impacts uf negative perceptions, data on noxious facilities sited throughout the United States were compiled, and secondary economic and demographic data sufficient to analyze the economic impacts on the surrounding study areas were assembled. This study uses wage rate and property value differentials to measure impacts on social welfare so that the extent to which noxious facilities and their associated acivities have affected surrounding areas can be determined.

The analysis of wage rates and property values in a variety of U.S. locations is central to this research. Differences in these economic measures are explained by identifying the differentiating characteristics of the areas being studied. Both amenities and disamenities associated with each location are identified and included in a hedonic modeling process. Hedonic models permit estimation of the value of environmental characteristics for which no market price is readily observable. For instance, hedonic analysis can identify the amount of housing value associated with features such as fireplaces, porches, pools, and central air-conditioning. In this study, hedonic methods are used to estimate the effect of various characteristics of a facility site (climate, labor market characteristics, population demographics, etc.) on area wages and property values.

To implement the hedonic regression analysis, cross-sectional data for 84 sites with and without noxious facilities were compiled. Four models were fully developed: income models for renters and home owners, a model of residential property values, and a residential rental market model. Both labor and land markets were analyzed because previous research has demonstrated that the impacts of regional amenities (or disamenities) can differ in sign and magnitude between wage and property markets.

Several analyses were undertaken to determine whether the categorizations used in this study are sound. For instance, we examined differences and similarities between sites with and without noxious facilities and found the areas to be similar in most resperts. The issue of whether renters and owners should be treated separately or as one group led to an analysis of their respective characteristics and the development of separate samples. The question of whether facility type and location characteristics affect population growth also 
was explored. Most facilities, other than nuclear power plants, were found to be associated with slower growth rates.

This analysis, which examines a cross-section of sites with and without noxious facilities that represent a broad range of location characteristics, has led us to determine that significant negative effects on property and wage markets are associated with some types of facilities. The research methodology does not assess the extent to which these impacts are caused by negative perceptions, however. The economic impacts estimated by this methodology are a net result of both positive or negative perception-based impacts and direct or indirect economic impacts due to the presence of, or activities at, the facility. Thus the finding of significant net negative impacts associated with a facility that stimulates the local economy indicates that the facility has resulted in substantial perception-based negative impacts. The perception of risk or nuisance effects from such a facility causes reduced demand for residences and reduced willingness to accept employment in the facility region, results that more than offset the employment and income generated in the area by the facility.

Overall, the hedonic models produce reasonable results. In the case of housing and individual attributes, for which coefficient magnitude can be evaluated easily, the estimates are reasonable, consistent, and stable across specifications. Results for the amenity variables are less consistent, and it is likely that some of the major area characteristics that affect location preferences are omitted. Further effort to augment the database or to try another approach to representing amenity types (such as factor analysis) is indicated. Facility variable results are stable and consistent across models for some facility categories but not for others.

Three facility variable specifications are examined. The first, density of all types of facilities combined, has a clearly negative impact on both owners and renters; it is associated with higher wage compensation and lower housing values. Results of the dummy variable specification by facility type are more difficult to interpret. It is apparent from the facility dummy variable specification that the presence of even one facility in an area generally has a statistically significant negative impact on owner-occupied housing values. This result indicates that a threshold effect occurs as markets adjust to the location of noxious facilities. Because the analysis is conducted on a regional (rather than neighborhood) basis, it is clear that the presence of one representative of a facility category is sufficient to generate small but identifiable property value impacts (averaged over a relatively large area). Estimates from the wage models for renters and for owners generally support this conclusion, although most of the coefficients are not significant. Rental housing values, in contrast, tend to increase if a noxious facility is present. Results of the facility density specification are similar with regard to the impact of each facility type. In general, property values decline and wages rise with increasing facility density.

In both the dummy and density variable specifications, the facilities with the most unambiguously negative impact are refineries. Next most negative are coal-fired power plants, followed by nuclear plants. The results for nuclear facilities are somewhat mixed, 
although clearly negative for home owners. Liquefied natural gas storage sites and hazardous waste sites are found to have positive impacts on property values. It is possible that variations in economic infrastructure have been partially captured by these facility variables. 


\section{INTRODUCTION}

Recent assessments of socioeconomic impacts resulting from the location of potentially hazardous facilities have concentrated on negative public perceptions and their resulting economic consequences. The economic effects of perceived risk, stigma, and negative imagery are called "perception-based impacts" because the resulting losses are not directly attributable to physical activity but are due to behavior modification that compensates for the perceptions of individual participants in the various markets. ${ }^{*}$ Recent research on these perception-based impacts has focused on developing methods for determining the extent to which locally undesirable activities can induce negative images. So far, however, little evidence supports the hypothesis that negative images alone will result in direct economic losses or impediments to economic development.

The most ambitious body of work to date on this subject has been performed by a group of researchers funded by the state of Nevada to determine the socioeconomic effects of the high-level radioactive waste repository scheduled to be constructed at Yucca Mountain. The report by Mountain West Research (1989) divides impacts into the categories "standard" and "special." Standard impacts develop either directly or indirectly from changes in regional employment and expenditures because of construction and operation of a facility, while special effects are perception-based impacts.

In the Mountain West report, the potential special effects from stigma, images, and perceptions of risk are discussed on the basis of results of numerous surveys and interviews conducted over the previous three years. The report mentions the following areas of pntential direct impact to the Nevada economy: property values, business location, retirement migration, tourism and conventions, and general economic development. Although the Nevada research developed methods for determining the effects that undesirable activities have on perceptions, very little has been done to estimate the extent to which these perceptions might cause measurable economic impacts.

Our analysis was designed to answer some of the questions left open by previous research on this topic. Although the "special effects" section of the Nevada report states that estimates of the potential socioeconomic impacts have not been completed, it does refer to impacts evidenced in other areas as a response to hazards of various types. The key question left unanswered is: Can economic impacts resulting from negative perceptions of noxious facilities be identified and measured?

\footnotetext{
"Rather than entering into an argument about the exact nature of the perception (i.e., whether or how it is related to physical risk), this analysis focuses on determining whether or not generally undesirable facilities may have measurable effects on the local economy that are unrelated to any economic activity associated with the facility and thus possibly due to perceptions.
} 
A related question is whether an ex post analysis of facility impacts has value in predicting future facility siting impacts due to negative perceptions. ${ }^{*}$ Ex post studies, such as this one, are necessary because ex ante evaluations of facility impacts can be based only on site and facility parameter relationships identified in analyses of past experience. What has been lacking in the field of impact analysis is documentation of correspondence between ex ante surveys and ex post impacts.

Previous studies suggest that negative images affect migration rates, business investment, new business formation, and recreation activity. Changes in these activities could lead to changes in property values, wage rates, and general economic development. These changes may also affect the public sector fiscally. Conflicting evidence on the occurrence, magnitude, and geographic extent of such impacts is found in the literature. The degref: to which impacts of perceptions vary with the type of facility, socioeconomic characteristics of the site area, or compensating or mitigating measures associated with the facility has not been investigated. In this context, this study was a first step in documenting the link between risk perception and wage and property market impacts.

\subsection{SCOPE OF THE RESEARCH}

To identify the impacts of negative perception.s, data for noxious facilities sited throughout the United States were compiled, and secondary economic and demographic data sufficient to analyze the economic impacts on the surrounding study areas were assembled. This study examined the extent to which certain facilities and their associated activities have affected the regions in question by using wage rates and property values to measure impacts on social welfare.

A static economic analysis of wage rates and property values in various U.S. locations is central to this type of research. Differences in these economic measures are explained by identifying differentiating characteristics of the areas being studied. Both amenities and disamenities are identified and included in the modeling process. The resulting impact estimates are a composite of "standard effects" and "special effects."

\subsection{REPORT STRUCTURE}

Background information related to economic theory and previous empirical studies is presented in Section 2, which also includes a discussion of the application of hedonic estimation methods to amenity valuation. The methods used to conduct this research are described in detail in Section 3. The rationale for the selection of study sites and facility types is also addressed, and the composition of the resulting representative sample is described. Section 3 concludes by presenting aspects of data set development and model specification. Research findings are covered in Section 4, which begins with analyses of three "In this report, ex post studies refer to studies based on data collected after a facility has been sited.
Ex ante studies are performed prior to or at the time of the siting decision, before construction begins, 
background issues: differences between sites with and without facilities, differences between housing renters and owners, and determinants of population change. The regression model estimates for owners and for renters are then presented, and the findings for various types of arnenities are summarized. Section 5 contains conclusions and recommendations for further research. The sites included in the study sample are listed in Appendix A. Appendix B lists the variables from the Public Use Microdata Sample of the 1980 Census of Population and Housing that were recoded or modified for the regression analysis and provides their definitions. Appendix $C$ gives definitions of the variables that are based on data from the County and City Data Book (U.S. Department of Commerce 1983). Finally, Appendix D lists the sources of facility information that were used as the basis for selecting the study sites. 


\section{THEORETICAL AND EMPIRICAL BACKGROUND}

In the past two decades, several methods for estimating the economic value (or cost) associated with different characteristics of a location have been developed and tested. The characteristics range from amenities such as "days of sunlight" or "proximity to recreational sites" to disamenities such as "air pollution concentration" and "distance from jet aircraft takeoff patterns." Some of these studies are more applicable to the impacts of noxious facilities than others. A compilation of the more relevant literature in this area can be found in Nieves et al. $(1990,1991)$. An overview of hedonic methods, results from some of the more pertinent empirical studies, and the theoretical basis for the present analysis are presented below.

\subsection{HEDONIC METHODS APPLIED TO AMENITY VALUATION}

Hedonic models can be used to estimate the value of environmental characteristics for which no market price is readily observable. For instance, hedonic analysis can identify the amount of housing value associated with features such as fireplaces, porches, pools, and central air-conditioning. It is applied in this study to estimate the effect of various characteristics of a facility site (climate, labor market characteristics, population demographics, etc.) on area wages and property values.

The hedonic technique assumes that individuals purchase goods because their attributes are desirable. Each attribute of a commodity has a specific effect on its price. Thus, adding or subtracting a unit of an attribute will either lower or raise the market price of the product in question. The econometric technique of hedonic price estimation can be used to identify the change in price that will result from changing an identified attribute. Hence, this method also can estimate the effect that locating a noxious facility near a house will have on its value (assuming nothing else changes).

The approach used in this research is based on methods explored in several recent articles that examine the joint effects of amenities on wage rates and property values. In all of these articles, the hedonic estimation technique is used to explain regional differences in wages and property values by treating these values as a function of numerous individual and location characteristics, including amenities.

Until recently, applications of hedonic methods focused on the implicit prices of attributes found in single markets, such as the property market. It was assumed that differences in living environments across locations we' $e$ valued in wage markets and that amenity differences within cities or regions were capitalized into property values. Henderson (1982) and Graves and Knapp (1985) explored the theoretical basis for valuing amenities and concluded that the effects of regional amenities are expressed simultaneously in both labor and property markets. Graves and Knapp indicated that impacts on wage and property markets can be either reinforcing or opposing, depending on the amenity's effects on labor productivity and personal consumption. This type of market equilibrium approach was 
demonstrated empirically by Roback (1982) and elaborated by Hoehn et al. (1987), using cross-sectional samples of U.S. cities to value amenities.

In the context of valuing public safety, Clark and Cosgrove (1990) demonstrated the possibility of estimating unbiased amenity values from single-commodity market data (as did. Henderson 1982). This approach is also based on general equilibrium analysis in the sense that if wage market data are utilized, the equation must control for rents, and if housing prices are used, wage effects must be controlled. Thus, it is theoretically possible to develop complete, confirmatory estimates of amenity values from the wage and property markets separately.

\subsection{FINDINGS OF PREVIOUS STUDIES}

Thaler and Rosen (1976) used the hedonic estimation method to measure the effects of job risk on equilibrium wage rates. Using 1967 data from the Survey of Economic Opportunity (SEO) ${ }^{*}$ for job-related variables and the Occupation Study of the Society of Actuaries to determine the risk measure (expected deaths) for each occupation studied, they conducted a cross-sectional analysis of earnings. Their research objective was to explain differences in wage rates as a function of job risk and other distinguishing characteristics. These characteristics included residence location, age, education, family size, race, unionization, type of industry, and type of assignment.

The Thaler and Rosen analysis provided results with implications for the present research. They were able to calculate a risk premium accepted by workers and paid by employers for a marginal increase in job risk. For example, jobs with extra risks of 0.001 (one death per thousand employees) paid $\$ 3.52$ per week more (in 1976) than jobs without this risk. In addition, their analysis found significant relationships between wage rates and the other characteristics modeled. This study also shed light on interactions between risk and such variables as age, marital status, union membership, and race.

Hageman (1981) developed a hedonic price model for the property market that incorporates the perceived risk of damage from proximity to a nuclear waste disposal site. Her model defines impacts in terms of economic activity effects and environmental quality effects, which may be mutually offsetting. Court litigation and economic studies were reviewed to determine the extent to which risk-related damages (as opposed to economic activity impacts) have been found. In addition, state officials and experts on economic impacts were interviewed. Only one litigated case was identified that supported the theoretical argument that fear of nuclear risks may produce negative economic impacts. In all of the other cases in which such impacts were claimed or suspected, the positive impacts of economic activity associated with the nuclear site operation appeared to have more than offset any negative effects.

\footnotetext{
"The SEO collects information on personal and industrial characteristics and labor force activities of individuals from low-income populations. The analysis used a random sample from this survey.
} 
Haurin (1980) addressed the extent to which climate affects migration rates between urban areas. His analysis considered two cities assumed to be identical in production technology except for the level of site-specific factors in thuded in the model. Climate differences were treated as a nontraded and nonproducible public good; hence, individuals who want to consume more or less of this good must change locations. The theoretical model was specified in a functional form that allowed solution for the endogenous price of housing and utility levels as a function of regional climate.

Haurin solved the model to show that (1) climate affects export production in that a city with a more favorable climate is larger and more laborers are drawn to it, (2) a more favorable climate is associated with higher housing prices and lower wage rates, and (3) an area with an inferior climate has higher wage rates and possibly reinforcing differences in housing prices. This work pr.vides a theoretical basis for the empirical work that follows.

Roback ( 1982 ) developed a simple general equilibrium model that focuses on the role of wages and rents in allocating workers to locations with various types and quantities of amenities. Her analysis compared productivity, wage rates, housing expenditures, and arnenities of different cities to determina the extent to which amenities affect social welfiare. The amenities included in the analysis were population size, population grnwth rate, climate variables, unemployment, and poverty incidence (to capture family background and schooling). Significant relationships were found for both wage and land price equations. This work demonstrates that unbiased amenity values can be measured from wage and rent differentials. It also shows that amenities are capitalized into wages and rents simultaneously, so that both must be modeled to estimate the amenity value accurately.

The model developed by Roback was extended by Hoehn et al. (1987), who used a general multimarket hedonic model to study the effects of amenities ou wages and housing prices. In a second study, Blomquist et al. (1988) derived an urban quality-ot-life index by considering the effect on land values and wage rates of the presence of Superfund sites; the presence of hazardous waste treatment, storage, and disposal sites; and the volume of landfill waste. In their approach, the full implicit price of an amenity is the sum of two components: an earnings differential and a housing price differential. It was shown that calculating the amenity value from one market alone captures only a partial price and can be misleading in both size and sign. They used interregicnal data to estimate the value of location-specific amenities more reliably.

Hoehn et al. (1987) estimated the values of 16 amenities by using data from the 1980 Census of Population and Housing. They augmented these data with information on school quality, crime, air quality, water quality, and toxic substances and found that amenities explain significant differences in housing prices and wage rates. A $10 \%$ improvement in the teacher-pupil ratio, crime rate, pollution level, Superfund sites, and other waste disposal sites is valued at approximately $\$ 21.2$ billion nationally, on the basis of full amenity values. If wage or property values alone are estimated, the valuation may be as much as $85 \%$ lower. Hoehn et al. found that all three noxious facility types significantly influence housing 
expenditures as well as hourly wage rates. The combined effect, which is reflected in the full implicit price, is nugarive, as expected. Superfund sites have the strongest marginal i. p..ct.

In another extension of the Roback work, Beeson and Eberts (1989) applied the hedonic model to explain differences in wages and housing prices across cities as a function of variation in amenities and productivity. They provided a theoretical model in which wage rates are separated into amenity and productivity components. The model was tested with the standard hedonic approach. Beeson and Eberts used the A and B samples of the Public Use -Vicrodata Sample (PUMS) from the 1980 Census of Population and Housing to estimate quality-adjusted wages and rents. They limited their sample to individuals who lived and worked in the same stanclard metropolitan statistical area (SMSA) and who changed addresses between 1975 and 1980 . This sample was selected to provide a better estimate of the market value of the house (because it had been sold more recently). Also, the analysis was limited to individuals between the ages of 25 and 55 who had worked more than 25 hours per week and had positive weekly earnings. Self-employed workers were not included in the sample.

The Beeson and Eberts study (1989) resulted in some interesting findings regarding the relationship between productivity (labor demand) and amenity (labor supply) influences. Although both components were important, the productivity component, on average, accounted for a larger share of the intermetropolitan wage differential. The productivity component accolnted for $60 \%$ of the variation in wage earnings, while the amenity component accounted for $40 \%$. In addition, the productivity and amenity components were found to be generally reinforcing (in 28 of 35 cities).

An important theoretical and empirical contribution to this area of research was provided by Henderson (1982), who examined interregional differences in welfare, concentrating on amenity and disamenity valuation. He developed theoretical constructs that were quite similar to Roback's; however, the role of regional price levels was treated explicitly in the specification. In addition. Henderson showed that the full implicit price can be derived from the wage equation alone if average land values are controlled adequately. Interesting findings from Henderson's empirical analysis include the difference in amenity valuations associated with variations in socioeconomic status.

Clark and Cosgrove (1990) note further that a model of intercity land rents, controlled for wages, can also be used to derive implicit prices directly. The controlled intercity hedonic model offers some distinct advantages. Specifically, it provides flexibility in derivation of implicit prices if precise information on both markets is not available. In addition, when both markets can be examined, the model affords an important internal test of consistency. Implicit prices should be comparable across the two controlled equations. Confidence can be placed in implicit prices that are of similar significance and magnitude across equations, while caution should be exercised when prices differ. 


\subsection{OVERVIEW OF THE THEORETICAL BASE}

This analysis extends the theoretical and empirical work described above. The problem facing the consumer is maximizing utility given the household budget constraint. We assume that households are mobile between cities and are aware of the amenity differences between cities. Within cities, amenity levels are assumed to be constant. Households maximize utility, which is a function of a composite good (X), land (L), and sitespecific amenities (A) subject to the available budget. The wage is $\mathrm{W}$, the price of lanc' is $\mathrm{R}$, and the composite good price is assumed to be the numeraire. ${ }^{\dagger}$ The equation system thus is:

$$
\begin{aligned}
& \mathrm{U}=\mathrm{U}(\mathrm{X}, \mathrm{L} ; \mathrm{A}) \\
& \mathrm{W}=\mathrm{X}+\mathrm{R} \times \mathrm{L}_{1}
\end{aligned}
$$

Maximizing Equation 1 subject to Equation 2 across the two goods, $\mathrm{X}$ and $\mathrm{L}$, results in Marshallian demand functions based on market prices and income levels. Substituting optimal $\mathrm{X}$ and $\mathrm{L}$ into the utility function results in an indirect utility function that can be considered equal to a constant, given the assumption of intercity mobility. The indirect utility function is a function of market prices and wages, as well as the amenity offerings between cities:

$$
\mathrm{V}^{*}=\mathrm{V}(1, \mathrm{~W}, \mathrm{R} ; \mathrm{A})
$$

where $\mathrm{V}^{*}$ is the level of satisfaction achieved. The sign of the first derivative $\delta \mathrm{V} / \delta \mathrm{A}$ depends on the type of characteristic. If the public views the regional characteristic as an amenity, the sign will be positive; if it is viewed as a disamenity, the sign will be negative. According to this model, earnings and property values will adjust to equalize utility across locations as long as the price vector for gonds other than land does not vary across regions. ${ }^{\dagger}$

Firms also are assumed to optimize inputs and location. Amenities can influence firm productivity directly. For example, if hazardous waste is generated in the production process, then an amenity such as low health risk for workers is costly to the firm. If it is assumed that the firm operates under conditions of constant returns to scale in competitive input and output markets, then cost minimization ( $\mathrm{TC}=$ total cost $)$ involves optimizing Equation 4, subject to the production constraint (Equation 5 ; where $Q=$ quantity), which results in the unit cost function (Equation 6 ). The term $\mathrm{N}$ represents the quantity of labor.

$$
\mathrm{TC}=\mathrm{R} \times \mathrm{L}+\mathrm{W} \times \mathrm{N}
$$

\footnotetext{
${ }^{\dagger}$ A numeraire is a commodity chosen to serve as a standard for measuring the relative prices of all commodities.

FControl of regional price variation has been treated in many ways in the hedonic modeling literature. We developed a city-specific price index, exclusive of housing costs, that is discussed in the next section.
} 


$$
\begin{aligned}
& G !=f(L, N ; A) \\
& 1=C(W, R ; A)
\end{aligned}
$$

For a given level of the amenity, a simultaneous solution of Equations 3 and 6 gives the equilibrium wage and rent levels:

$$
\begin{aligned}
& W=W(R, A) \\
& R=R(W, A)
\end{aligned}
$$

The inplicit price of the amenity derived from Equations 7 and 8 is a joint function of its marginal impacts on wages and rents:

$$
\mathrm{P}^{*}=\mathrm{W} \times \mathrm{k}_{\mathrm{l}} \times \mathrm{dln} \mathrm{R} / \mathrm{Da}-\mathrm{W} \times \mathrm{dln} \mathrm{W} / \mathrm{Da}
$$

The fraction of income spent on land is represented by $k_{1}$, so the expenditure on land ( $W \times k_{1}$ ) provides the weight on the rent component of the implicit price. However, Henderson (1982) showed that, if rent levels are controlled, Equation 7 alone can be used to derive implicit prices. Clark and Cosgrove (1990) further established that Equation 8 can yield fu'! implicit prices if wages are controlled. We estimate controlled intercity wage and rent functions. 


\section{METHODOLOGY}

In this section we discuss the research approach: a hedonic interregional analysis. Then the issues and constraints affecting study area selection are described, as is the composition of the resulting sample. Details of data set development for each category of variables are presented last.

\subsection{RESEARCH APPROACH}

This study has sought to ascertain the impacts of "special effects" to the extent that they are reflected in the economic behavior of the affected population. Two economic indicators of the combined impacts of standard and special effects are analyzed: property values and wages. The analysis employs a hedonic regression involving U.S. cross-sectional data for 74 noxious facility sites and 10 sites without such facilities.

The hedonic estimation approach used in this study is based on Roback (1982) and Henderson (1982), which are discussed in the review of methodology in Section 2.1. We analyze both wage and property market data because thenretical and empirical studies have indicated that single-market estimates of amenity values can be biased if not properly controlled. Use of both markets can confirm the robustness of impact estimates. Following the example of Clark and Kahn (1989), we include variables to control for the possible market effects of disequilibrium conditions. This inclusion avoids reliance on the assumption that all study-area property and wage markets were in a state of equilibrium when the data were collected.

Impacts associated with a noxious facility can be measured by using either timeseries or cross-sectional data (or a combination of the two). Time-series data offer advantages in measuring changes in impact indicator variables while implicitly controlling variables associated with the location of sample units. By covering the periods before and after facility siting, a time-series analysis can provide, respectively, a benchmark for the original state and a measure of the equilibrium reached after people have adjusted their behavior to the changed situation. A disadvantage of this method is that it is difficult to know in advance whether the data actually bracket the adjustment period. We did not implement this approach because a time-series database for wages and property values covering either the variables or geographical areas required for this study was not available. The lack of suitable time-series data has constrained most hedonic analyses, including those reviewed in Section 2.2 , to use of cross-sectional data.

However, cross-sectional analysis can reveal much of the same information if the sample of sites is sufficiently large and is selected to represent the range of key characteristics. When using cross-sectional data, features that vary across sites and that may affect wage or property price levels (such as climate) must be explicitly modeled to avoid biasing impact estimates. The inclusion of control sites matched to the facility site sample has an effect in cross-sectional analysis that is analogous to the before-and-after facility siting 
information available from time-series data. Although use of combined time-series crosssectional data would incorporate the advantages of both approaches, cross-sectional data alone are adequate for the estimation task.

To use cross-sectional U.S. data to estimate facility impacts, one must first determine whether market structure is sufficiently homogeneous to estimate one model for the nation or whether regional markets differ so much tnat they should be modeled separately. This issue is more germane to housing markets, because property is immobile, than it is to labor. Trade-offs among housing characteristics that differ substantially across locations may indicate the existence of separate regional submarkets, which would limit the potential for determining a single value for each amenity regardless of location.

Butler (1980) addressed this concern by using 1960 Census of Population and Housing data for 36 large urban areas to examine both structural relationships among housing characteristics (hedonic variable coefficients) and housing price levels (equation intercepts). He found the rental housing market to be quite homogeneous in terms of structure, although with some variation in price level. Owner-occupied housing showed significant differences in market structure as well as variation in price levels. These differences appear to reflect the costs of different construction methods required to deal with climate variations. After examining the effects of submarket variation, Butler concluded that although the variation is significant, its effect on the explanatory power of the hedonic equations and its effect on coefficient accuracy are slight. Therefore, we adopted the approach of estimating a pooled cross-sectional model for the United States, with dummy variables for the nive census divisions to allow for regional differences in climate and other factors.

\subsection{STUDY SITE SELECTION}

The selection of the study site sample was governed by the desire to include the full range of variation in the major variables. As a first step, eight different types of facilities that present some nonzero potential for harm to persons and/or the environment were selected for study. Ifo attempt was made to measure the physical risks associated with the facilities, which may be due to radiation, toxic chemicals, flammability, or some combination of these characteristics. The focus in this study is only on the measurability of impacts.

In the second step, specific facilities of each type were selected to incorporate a wide range of characteristics such as site size, surrounding land use, proximity to other facilities, and level of public controversy associated with the facility. These facilities were chosen with a view to possible future analysis of case study information. The data units in which these facilities are located. with geographic boundaries defined by the 1980 PUMS, make up the study site sample for the analysis. In addition, sites without any such facilities are included to provide a baseline measure.

The analysis; also includes any facilities, other than those selected in the second step, that are within the PUMS data unit boundaries, thus greatly expanding the number of 
facilities in the sample. Because of the size of PUMS data units and the facility sample structure, the analysis focuses on identifying the diffuse impacts of each type of facility ( rather than of a specific facility) over broad geographic areas.

\subsubsection{Determination of Facility Categories}

Eight categories of facilities were included in the study sample:

1. Nuclear-powered electric generating plants,

2. Coal-fired generating plants,

3. Gas- and oil-fired generating plants,

4. Military chemical weapons storage sites slated for decommissioning (CHEMDMIL sites),

5. Hazardous waste sites,

6. Petrochemical refineries,

7. Radioactively contaminated sites managed by the U.S. Department of Energy (DOE) under the Formerly Utilized Sites Remedial Action Program (FUSRAP), and

8. Liquefied natural gas (LNG) storage facilities.

Power plants fired by natural gas or oil were combined into a single category ( 3 ) because often both fuels are used on a single site and consequently it is difficult to differentiate their impacts. The hazardous waste sites category (5) includes both chemical and radioactive waste sites. All of the chemical waste sites existed in 1980 and are listed on the U.S. Environmental Protection Agency's National Priorities List. However, the extent of local information about these sites before they were identified as Superfund sites is unknown." The hazardous waste sites category also includes two currently operating commercial facilities for disposal of low-level radioactive waste. Two facility categories (4 and 7) are under federal ownership or management and are involved in the storage or disposal rather than the production of hazardous materials. One category, the FUSRAP sites (7), which were identified as part of DOE's efforts, contain residual radioactive contamination from materials produced for the Manhattan Project or subsequent projects and are not associated with ongoing operations. Although Weldon Springs is a Superfund site, it is included in the FUSRAP group because DOE is cleaning it up. The second category (4), referred to as

"The National Priorities List of uncontrolled hazardous waste sites was established by the Comprehensive Environmental Response, Compensation and Liability Act of 1980, as amended by the Superfund Amendment and Reauthorization Act of 1986. 
CHEMIDMIL, consists of chemical weapons storage sites that have been designated for decommissioning by the U.S. Department of Defense.

\subsubsection{Selection of Study Sites}

After the facility categories were determined, the second step in sample development was to select specific facility sites. This step involved the development of background information on facility locations and sires without any noxious facilities. Sites were then selected if they contained the type of facility whose representation in the sample was desired or, alternatively, if they contained none of these types of facilities (for the control group).

\subsubsection{Sites with Noxious Facilities}

The selection of noxious facility sites was constrained by a desire to include sites containing facilities that had already been $t$ ! e subject of a case study or socioeconomic impact analysis. This restriction was imposed on sample development to permit future in-depth analysis, with available documentation, of factors affecting noxious tacility siting success. However, this restriction was not imposed on CHEMDMIL, refinery, or L.NG storage sites because such documentation is largely unavailable to us. To be candidates for site selection, facilities had to be either in operation or, in the case of a few large coal and nuclear plants, in the final stages of construction by 1980 .

An additional constraint on site selection was imposed by the geographical area aggregation in PUMS. To protect individual confidentiality, the geographical areas defined in the PUMS database must have a population of at least 100,000. Sparsely populated areas thus produce very large geographical data units." Facilities located in data units composed of noncontiguous geographical areas were excluded from the sample.

Because of these constraints, the study sample was not selected randomly. Instead, it was developed with the goal of providing a representative sample covering the full range of variation in theoretically key variables. In most categories, facilities were selected to represent all U.S. regions. The sites are listed in Appendix A.

All existing CHEMDMIL sites were included, except those for which PUMS geographical areas were inappropriate for this analysis. The same is true for all of the major FUSRAP sites that have developed remedial action plans. Most of the coal and nuclear plants selected had already been included in major post-construction socioeconomic impact evaluation studies carried out by the Electric Power Research Institute and the Nuclear Regulatory Cornmission. All Superfund sites for which the Office of Technology Assessment had completed a detailed review of progress were included. The sources of facility-related information that led to selection of the study sites are listed in Appendix D.

\footnotetext{
"The U.S. Bureau of the Census numerical codes for the data units and their dimensions in square miles are given in Appendix A. The size range is 22 to 36,367 square miles.
} 


\subsubsection{3ites without Noxious Facilities}

Geographic units were included as baseline or control sites if it was verified that no facilities of any of the types studied were within the area boundaries. Any of these sites, and the facility sites, could contain other noxious facilities or characteristics, such as sewage treatment plants, landfills, or naturally occurring hazards. The control sites were included to establish baseline market levels, not to reflect risk-free conditions. Inclusion of these sites broadened the sample to include the full range of independent variables.

Lists of FUSRAP, CHEMDMIL, LNG storage, and nuclear-, coal-, and oil-fired power plant sites were used to eliminate their locations from consideration as control sites. Additional lists of gas-turbine power plants were used to supplement a list of gas-fired steam generators. Refinery locations were identified from the U.S. Manufacturers Directory published by American Business Directories, and hazardous waste sites were identified from. the National Priorities List of hazardous waste and Superfund sites. The possible presence of noxious facilities was also checked through calls to the relevant chambers of commerce and state or regional offices responsible for hazardous waste management. Appendix D lists these information sources.

The original goal was to identify three baseline sites in each of four U.S. Census Regions (West, South, Northeast, and North Central). However, very few candidate control sites remained after the PUMS geographical data unit constraint described above was imposed and after the sites containing a noxious facility were eliminated. As a result, it was not possible to identify any control sites in the Northeast, and only two could be identified in the West. Three sites were identified in the North Central Region and five were identified in the South, producing a total of 10 control areas. Three of the control sites were multicounty data units that have one noxious facility in the multicounty unit but not in the primary county selected as a control area. Although this fact dilutes the effectiveness of the control group somewhat, the impact on the analysis was expected to be negiigible because of the large number of sites and facilities involved. Results of the hedonic regression analysis do not depend in any way on the definition of noxious facility and control sites.

\subsubsection{DISTRIBUTION OF STUDY SITES AND FACILITIES}

Most of the study sites contain more facilities than the one originally selected for inclusion in the sample. For example, a study site may contain a nuclear plant, a coal-fired plant, and a hazardous waste facility. Because any of the facilities at a site may cause economic impacts, all of the facilities identified in a geographic data unit were incorporated in the analysis.

The distribution of the 84 study sites among the U.S. Census Regions is shown in Table 1. The primary facility type indicates which type of facility led to the site's inclusion in the study. This table does not show the total number of facilities of each type included in 
TABLE 1 Number of Study Sites in Each of Four Census Regions

\begin{tabular}{|c|c|c|c|c|c|}
\hline \multirow[b]{2}{*}{ Study Site } & \multicolumn{5}{|c|}{ Number of Study Sites in Each Census Region } \\
\hline & North Central & Northeast & South & West & Total U.S. \\
\hline Nuclear & 1 & 7 & 5 & 3 & 16 \\
\hline Coal & 2 & 2 & 2 & 3 & 9 \\
\hline Gas/oil & 3 & 2 & 3 & 2 & 10 \\
\hline CHEMDMIL & 1 & 0 & 3 & 3 & 7 \\
\hline Hazardous waste & 4 & 1 & 3 & 2 & 10 \\
\hline Refinery & 2 & 1 & 4 & 2 & 9 \\
\hline FUSRAP & 2 & 4 & 0 & 0 & 6 \\
\hline LNG & 1 & 3 & 3 & 0 & 7 \\
\hline Control & 3 & 0 & 5 & 2 & 10 \\
\hline Total & 19 & 20 & ¿o & 17 & 84 \\
\hline
\end{tabular}

a A study site is identified by its primary facility type The primary facility type is the type of facility that led to inclusion of a particular site in the study. Facilities of other types may also be located on the site. Control sites have none of these facilities.

the analysis, except for CHEMDMIL and FUSRAP facilities. Virtually all of the major facilities of these types are located in areas whose primary facility type is CHEMDMIL or FUSRAP.

The expanded set of facilities grouped by site category (primary facility type) is shown in Table 2. The first line shows that the 16 areas selected because of well-studied nuclear plants also contain 3 coal-fired generating plants, 10 gas- or oil-fired plants, and 27 hazardous waste sites. Column totals represent the total number of facilities of each type accounted for in the analysis. Inclusion of all facilities located in the selected study areas expanded the sample to 293 facilities. Of the facility types, the gas-, oil-, and coal-fired plants have the lowest rate of siting overlap with other types of facilities, while FUSRAP and LNG storage sites have the highest numbers of other facilities per site.

The distribution of the expanded set of noxious facilities among the Census Regions is shown in Table 3. The Northeast contains the largest number of facilities (91), mainly because of the large proportion of hazardous waste sites in that region. The distribution of most facility types appears to mirror the distribution of the total population of facilities across regions.

\subsection{DATA SET DEVELOPMENT}

Data from several sources were combined to construct a data set that provides sufficient information for this cross-sectional analysis. The data for each site cover wage and 
TABLE 2 Number of Noxious Facilities in All of the Study Sites

\begin{tabular}{lrrrrrrrrr}
\hline & \multicolumn{8}{c}{ Number of Facilities at Each Sit } & by Type \\
\cline { 2 - 9 } Study Site $^{\mathrm{b}}$ & NUP & COP & GOP & CHM & HWS & PCR & RAC & LNG & Total \\
\hline Nuclear & 16 & 3 & 10 & 0 & 27 & 0 & 0 & 0 & 56 \\
Coal & 0 & 27 & 4 & 0 & 3 & 4 & 0 & 0 & 38 \\
Gas/Oil & 0 & 3 & 16 & 0 & 6 & 2 & 0 & 0 & 27 \\
CHEMDMIL & 0 & 6 & 2 & 7 & 6 & 2 & 0 & 0 & 24 \\
Haz. Waste & 1 & 7 & 4 & 0 & 23 & 4 & 0 & 2 & 41 \\
Refinery & 1 & 4 & 10 & 0 & 6 & 21 & 0 & 0 & 42 \\
FUSRAP & 0 & 3 & 2 & 0 & 13 & 2 & 6 & 0 & 26 \\
LNG & 2 & 2 & 7 & 0 & 13 & 3 & 0 & 9 & 36 \\
Control & 1 & 1 & 1 & 0 & 0 & 0 & 0 & 0 & 3 \\
Total & 21 & 56 & 56 & 7 & 98 & 38 & 6 & 11 & 293 \\
\hline
\end{tabular}

a A study site is identified by its primary facility type. The primary facility type is the type of facility that led to inclusion of a particular site in the study. Facilities of ocher types may also be located on the site. Control sites have none of these facilities.

${ }^{\mathrm{b}}$ NUP = nuclear plant; $\mathrm{COP}=$ coal-fired plant; $\mathrm{GOP}=$ gas- or oil-fired plant; $\mathrm{CHM}=$ chemical weapons storage site slated for decommissioning; HWS = hazardous waste site; $\mathrm{PCR}=$ petrochemical refinery; $\mathrm{RAC}=$ formerly utilized, radioactively contaminated site (FUSRAP) managed by DOE; LNG = liquefied natural gas storage facility.

TABLE 3 Number of Noxious Facilities in Each of Four Census Regions

\begin{tabular}{lccccccccc} 
& \multicolumn{8}{c}{ Number of Facilities in Each Census Region, by Type } & \\
\cline { 2 - 9 } \multicolumn{1}{c}{ Region } & NUP & COP & GOP & CHM & HWS & PCR & RAC & LNG & Total \\
\hline \multirow{2}{*}{ Northeast } & 7 & 10 & 14 & 0 & 47 & 5 & 4 & 4 & 91 \\
North Central & 1 & 24 & 18 & 11 & 5 & 7 & 2 & 1 & 69 \\
South & 7 & 11 & 15 & 3 & 20 & 16 & 0 & 5 & 77 \\
West & 6 & 11 & 9 & 3 & 16 & 10 & 0 & 1 & 56 \\
Total & 21 & 56 & 56 & 17 & 98 & 38 & 6 & 11 & 293 \\
\hline
\end{tabular}

a NUP = nuclear plant; $\mathrm{COP}=$ coal-fired plant; GOP = gas- or oil-fired plant; CHM = chemical weapons storage site slated for decommissioning; HWS = hazardous waste site; $\mathrm{PCR}=$ petrochemical reginery; $\mathrm{RAC}=$ formerly utilized, radioactively contaminated site (FUSRAP) managed by DOE; $L N G=$ liquefied natural gas storage facility. 
property markets, local amenities and disamenities, and socioeconomic structure. All of the data are for 1980 .

\subsubsection{Wage and Property Market Data}

Data for wages, residential property values, and associated individual attributes needed for a hedonic analysis were taken from PUMS. The B sample was used because it provides finer geographic resolution in urban areas than the A sample. To protect data confidentiality, no geographical data unit in either sample has a population of less than 100,000. Therefore, sparsely populated areas resulted in large, multicounty data units. Another weakness in these databases is that noncontiguous areas were sometimes combined to create data units with populations of more than 100,000. The databases are, however, the only identified source of individial records that cover the theoretically relevant variables for both rural and urban U.S. locations for a given year.

\subsubsection{Wage Market Sample and Variables}

The initial sample of persons for the wage market analysis was drawn on the basis of residence in one of the study sites. Because the analysis sought to capture possible impacts of noxious facilities on local markets, only individuals who also worked in the study area were retained in the sample. This restriction was imposed so that the wages and property values analyzed would reflect the impacts of facilities within the study areas. In smaller, more densely populated geographic areas, a higher proportion of residents may be commuters and thus be eliminated from the data set. The sample of workers used io estimate wage equations is composed of those at least 18 years old wh o reported wage and salary income or nonfarm self-employment income. ${ }^{*}$ The sample is also confined to workers who earned calculated wages of more than $\$ 2$ per hour. ${ }^{\dagger}$ Becaus the PUMS income data distribution is truncated, the income category of "\$75,000 and up" was omitted from the analysis. The final sample size is 25,279 cases: 7,215 renters and 18,064 owners.

Some of the PUMS variables required recoding or other modification to facilitate analysis. These changes are listed with the variable definitions in Table B.1 (see Appendix B).

\subsubsection{Residential Property Market Sample and Variables}

Two . sparate samples consisting of 47,947 owned units and 12,457 rentals were constructed on the basis of the following selection criteria. Group quarters, vacant units, and

\footnotetext{
"Farm income was omitted because it may incorporate returns to farmland and buildings.

tThose who reported hourly earnings of less than $\$ 2$ were dropped because of the likelihood of underreporting.
} 
units lacking individual access are excluded from the samples. Residences used for commercial purposes and rental units for which no cash rent was paid also are excluded. The PUMS rental and property value data for rents in the category "\$999 and up," as well as estimated market values in the category "\$175,000 and up," are excluded.

Variables related to the residential property market taken from PUMS are listed in Table B.2 (see Appendix B). Coding modifications to facilitate analysis are included with the variable definitions.

\subsubsection{Amenity/Disamenity and Control Data}

Local amenities or disamenities that may affect people's valuation of property and the compensation that they are willing to accept for employment in a given location include climate, cultural and educational opportunities, factors affecting health and safety, and fiscal characteristics. Data for many types of amenities and disamenities identified in the literature are available for 1980 from the County and City Data Book (U.S. Department of Commerce 1983). In addition, some factors that may affect local market structure or clescribe the living environment are used as controls. All of the variables for which data were taken from the County and City Data Book are listed and defined in Appendix C. Data for additional variables were developed from other sources, which are described in later subsections.

In all cases, the county and city data selected for inclusion in the data set are those which most closely correspond geographically to the PUMS data unit for each study site. However, for PUMS data units that consist of subcounty or multicounty areas, there is a degree of geographical mismatch that decreases the precision of the study findings.

\subsubsection{Cost of Living}

To control for the relative cost of living (excluding housing, which is controlled separately), an index for 1980 was computed from Inter-City Cost of Living Indicators, compiled for 234 cities (American Chamber of Commerce Researchers Association 1980). The computed index (COLNDX) is for all items except housing and uses the same weighting of components as the U.S. Department of Commerce does in its Consumer Price Index. Relative component weightings are as follows: grocery items (24), utilities (12), transportation (15), health care (8), and miscellaneous goods and services (16).

\subsubsection{Unionization}

Kokkelenberg and Sockell (1985) provide rates of union membership for members of the population older than 14 for all states and selected SMSAs for 1980. Cities are matched to the PUMS geographical data units whenever possible; otherwise the state-level unionization rates are used. This variable is labeled PUNION. 


\subsubsection{Location}

To represent the amenity value of water-based recreation, a dummy variable for coastal location was created. COAST is set equal to one for data units on sea coasts. In addition to providing recreational advantages, a coastal location also may affect production positively through lower transportation cost (i.e., agglomeration in transportation).

Market effects of regional location are controlled through a set of regional dummy variables. These represent nine U.S. Census Divisions as follows:

- PAC Pacific

- MT Mountain

- WNC West North Central

- ENC East North Central

- MA Middle Atlantic

- NE New England

- SA South Atlantic

- ESC East South Central

- WSC West South Central

\subsubsection{Climate}

The variable PCTSUN, which represents the percentage of potential sunlight reaching the earth's surface, was taken from the National Oceanic and Atmospheric Administration's Comparative Climatic Data for the United States through 1987 (NOAA undated). Precipitation (PRECIP) was taken from the same source. Values for both variables are annual averages.

Anmual average data are also used for total suspended particulate (TSP) concentrations, Readings from the nearest monitor available in 1979 are used for each study area. Missing values were calculated by averaging data from monitors adjacent to the study area. The data are from the SAROAD database (Garvey et al. 1982).

Data for the other climate variables are from the County and City Data Book. These include heating-degree-days (HEATDAYS) and cooling-degree-days (COOLDAYS) (measures of temperature deviation from 65 degrees) and the difference between average mean daily temperatures in July and January (TEMPDIFF). 


\subsection{MODEL SPECIFICATION}

Four models were fully developed to analyze the impacts of noxious facilities on the surrounding area: income models for renters and home owners, a model of residential property values, and a residential rental market model. Both labor and land markets were analyzed because, as discussed above, previous research has demonstrated that the impacts of regional amenities (or disamenities) can differ in sign and magnitude between wage and property markets depending on the amenity's effects on consumers and producers (Roback 19.82). It was expected that analysis of both rental and owned-property markets would confirm evidence of impacts.

Endogenous control variables were employed on the basis of Henderson's (1982) finding that the amenity impact can be fully captured in estimates for just one of the markets if effects on the other market are simultaneously controlled. Because of the resulting simultaneity in the model structure, twon-stage least squares (2SLS) techniques were used in the estimation. For each data unit, the mean levels of work experience, marital status, and grade attained for renters and owners combined were used as instrumental variables in the property market equations, and mean levels of building age, number of bedrooms, number of bathrooms, condo status, and acreage greater than one (for home owners) were used similarly in the income models. Double-log forms were estimated because of the underlying nonlinearity of the models. Nelson (1978) established that the double-log form places the fewest restrictions on the implicit price function. The general form of the estimated models is:

$$
\begin{aligned}
& \text { ANNWAGE }=\mathrm{W}\left(H C \& I I N D, P R I C E, D I S E^{\prime} Q, A M E N I T Y, N O X I O U S\right) \\
& \mathrm{VALUE}=\mathrm{V}(S T R U C T, P R I C E, D I S E Q, A M E N I T Y, N O X I O U S)
\end{aligned}
$$

Independent variable headings for human capital and industry controls (HC\&IND) are included in the wage equation, while housing structural characteristics (STRUCT) are included in the housing value equation. Additional independent variables include local prices (PRICE), disequilibrium controls (DISEQ), control amenities (AMENITY), and noxious facilities (NOXIOLS). The bases for selecting the variables in each of these groups are discussed below, along with aspects ot the data employed in the estimation.

\subsubsection{Wage-Related Variables}

Annual wages (ANNWAGE), the summation of annual wages and self-employment income, is the dependent variable in the wage model. The vector of human capital and industry characteristics (HC\&IND) includes the sex of the worker (SEX), marital status (MARITAL), a sex and marital status interaction term (SEXMAR), years of education (EDUC), experience and experience squared (EXPER and EXPERSQ), race (WHITE), and dummies for full-time employment (FULLTIME), veteran status (VETERAN), and partial disability status (DISABLE). In addition, two sets of dummy variables represent the 
occupation and industry of the worker." The latter category is included to control for differences in occupational risk across industries. Farming and fishing combined is treated as the reference occupational category, and manufacturing is the reference industry. Finally, annual hours of work (ANNHOURS) is included to proxy work effort. The variables, their definitions, and some coding comments are listed in Table B.1 (see Appendix B).

\subsubsection{Housing-Related Variables}

In the owners sample, annual housing value is derived from the owner's estimate of the market sales value of the residence. ${ }^{\dagger}$ It can be experted that people who have purchased most recently will provide the most accurate value estimates. Accordingly, the time period that has passed since the owners moved into the house (YRMOVED) is included in the equation to account for variation in accuracy over time. Structural characteristics (STRUCT') of the housing unit are controlled through several measures. These include the building age (BLDNGAGE), number of bedrooms (BEDROOM), number of bathrooms (BATHROOM), number of other rooms (OTHRROOM), a dummy for central air-conditioning (CENTAIR), and a dummy indicating whether the unit is a separate building (DETACHED). Features such as type of water system (WATER), sewer system (SEWAGE), and heating system (HEATING), as well as large lot size (ACREGT1), are controlled with dummy variables. Finally, condominium status is also controlled with a dummy variable (CONDO).

The dependent variable in the rental property equation (RENT2). represents the annual contract rent plus all separately paid utilities, making it a comprehensive measure of the annual value of housing services. YRMOVED is included in the rental market model to account for possible stability of rents over time when the occupancy of a unit is unchanged. The renters model contains the same variables as the owners model, with the exception of omitting CONDO and ACREGT1 and adding the number of units in the building (UNITS1). These variables are documented in Table B.2 (see Appendix B).

\subsubsection{Control Variables}

Equations 10 and 11 share many of the same variables. Before the differences are discussed, the common vaiiables are briefly reviewed. The PRICE category contains a cost of living index (COLINDX), computed without the cost of housing, to account for the relative cost of produced goods. Income effects on the property market are controlled by median

\footnotetext{
"Occupation dummies include farming and fishing; managerial and professional specialties; operators, fabricators, and laborers; precision production, craft, and repair; service; and technical, sales, and administrative support. Industry dummies include agriculture; forestry and fisheries; construction; entertainment and recreation services; business and repair services; mining; public administration; professional and related services; wholesale and retail trade; and transportation, communications, and other public utilities.

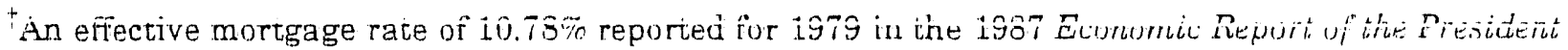
was used. This rate includes prepaid points and assumes repayment after 10 years.
} 
household income (MEDHSINC) in the housing models. Housing price effects are controlled in the owner and renter labor market models by either the median value of owner-occupied housing units (HMEDVAL) or by the median value of rental units (RMEDVAL).

The DISEQ category controls for the possibility of temporary disequilibrium. Included are the unemployment rate (PUNEMPL), the percentage of the labor force that is unionized (PUNION), and regional dummy variables representing the nine Census Divisions. The percentage of year-round housing units that remain vacant (VACANCY) controls for disequilibrium effects in the housing market.

Control amenities (AMENITY) are related to safety, climatic, environmental, and recreational conditions in the region. The violent crime rate (CRIME) represents the public safety amenity, while several measures are used to control climate. These measures include the average annual percentage of available sunlight (PCTSUN), the average annual inches of precipitation (PRECIP), the difference between the average mean daily July and January temperatures (TEMPDIFF), and the average total cooling-degree-days (COOLDAYS) and heating-degree-days (HEATDAYS). The variable for particulate concentration (TSP) approximates air quality in the region, and a dummy variable representing coastal locations (COAST) approximates water-based recreational amenities. Amenities and disamenities associated with urban scale are represented by population density (POPDENS) and by dummy variables defining the metropolitan status of the county (CNTRLCTY and RURAL). Locations within an SMSA but outside the central city are used as the reference case. Finally, the effects of industrial concentration (e.g., congestion and pollution) are controlled by the percentage of total employment represented by manufacturing workers (PCTMFG).

\subsubsection{Facility Variables}

Noxious facilities are modeled in several different ways, the goal being to fully explore the nature of their impacts. First, the impact of the presence of noxious facilities is measured in terms of the density of all facility types per 100 square miles (ANYNFDNS). To account for the possibility of an impact threshold, dummy variables are included for the presence of at least one tacility in each of the eight categories of noxious facilities (DNFxxx, with the last three letters designating facility type). Because it is possible that marginal impacts depend on the number of facilities in the area, the density of each type of facility (NFDNSxxx) is also modeled."

\footnotetext{
"In the facility variables, facility type is designated by the abbreviations used in Table 2 : NUP = nuclear power plant, $\mathrm{COP}=$ coal-fired plant, $\mathrm{GOP}=$ gas- or oil-fired plant, $\mathrm{CHM}=$ military chemical weapons storage site, $\mathrm{HWS}=$ hazardous waste site, $\mathrm{PCR}=$ petrochemical refinery, $\mathrm{RAC}=$

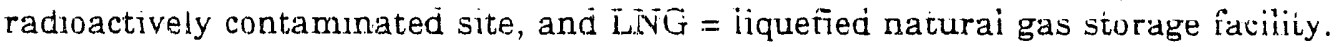




\section{DISCUSSION OF FINDINGS}

This section first presents the results of descriptive and background analyses that contribute to an understanding of the hedonic analysis results. These analyses pertain to the comparability of sites with and without facilities, the degree of similarity between housing owners and renters, and the relationship between population change and noxious facility locations. In the final portion of the chapter, results of the hedonic analysis are presented and discussed.

\subsection{BACKGROUND ANALYSIS}

Several analyses were undertaken to determine whether the categorizations used in this study were sound. For instance, we examined differences and similarities between sites with and without noxious facilities. The issue of whether renters and owners should be treated separately or as one group led to an analysis of their respective characteristics. The question of whether population change is affected by facility type and location also was explored. The background analyses related to these issues are briefly summarized in this section.

\subsubsection{Comparison of Sites with and without Noxious Facilities}

Data from the County and City Data Book were used to compare economic and demographic aspects of the control and noxious facility study sites. To determine if significant differences exist, we tested the null hypothesis that the mean values of each variable were equal for the control and facility site groups. The results of this analysis, grouped by statistical decision category, are shown in Table 4. Although a large number of variables were used in this analysis, results are reported for selected representative variables.

On the basis of this analysis, we conclude that the areas without facilities are sufficiently similar to the noxious facility sites to provide a baseline for regression and other statistical analyses. Although the populations and economies of the noxious facility sites are larger in absolute terms, they are essentially equivalent when considered in terms of rates. For instance, the mean number of high school graduates is significantly different, but the percentage of high school graduates is not. The control and facility site groups are also climatically equivalent.

The hypothesis of equal means for sites with and sites without noxious facilities cannot be rejected for any of the variables representing population-based rates or economic measures. These variables include the median values of homes (HMEDVAL) and rental units (RMEDVAL) as well as income per capita (INCPERCP). This equality is also observed for all five climatic measures. These findings indicate that the control and facility site groups are not significantly different. 
TABLE 4 Comparison of Variable Means for Sites with and without Noxious Facilities $\left(H_{o}: X_{w}=X_{w o}\right)$

\begin{tabular}{|c|c|c|}
\hline \multirow[b]{2}{*}{ Variable } & \multicolumn{2}{|c|}{ Mean } \\
\hline & $\begin{array}{c}\text { Sites without } \\
\text { Noxious Facilities }\end{array}$ & $\begin{array}{c}\text { Sites with } \\
\text { Noxious Facilities } \\
\end{array}$ \\
\hline \multicolumn{3}{|c|}{ Reject $H_{0}$ at 0.01 level: } \\
\hline CITY AREA & 27.60 & 58.87 \\
\hline COLLEGE & 7275.80 & 32932.14 \\
\hline FAMPOVTY & 1755.70 & 7468.16 \\
\hline GENREVNU & 39370.00 & 275749.76 \\
\hline HISCHOOL & 27584.70 & 131657.91 \\
\hline POPDENS & 126.01 & 649.58 \\
\hline POPOVR25 & 40315.80 & 189689.80 \\
\hline TAXES & 15266.30 & 121955.28 \\
\hline UNEMPLY & 2293.10 & 10612.92 \\
\hline Reject $H_{0}$ at 0.05 & & 76750 \\
\hline HOSPITAL & 370.01 & $7 t 57.05$ \\
\hline \multicolumn{3}{|l|}{ Cannot reject $H_{0}$ : } \\
\hline CNTYAREA & 880.30 & 1501.84 \\
\hline COLINDX & 99.52 & 101.46 \\
\hline CRIMES & 373.78 & 534.99 \\
\hline FARMLAND & 194819.50 & 386336.29 \\
\hline GOVSPEND & 611.80 & 736.55 \\
\hline HMEDVAL & 45920.00 & 45189.47 \\
\hline INCPERCP & 6521.90 & 7032.58 \\
\hline JANTEMP & 36.07 & 33.74 \\
\hline JULYTEMP & 75.40 & 75.80 \\
\hline MEDHSINC & 15602.20 & 16693.47 \\
\hline PCTCOLG & 15.17 & 14.57 \\
\hline PCTFARM & 42.05 & 39.56 \\
\hline PCTHISCL & 64.02 & 65.63 \\
\hline PCTPOVTY & 10.72 & 9.25 \\
\hline PUNEMP & 7.51 & 6.59 \\
\hline PUNION & 17.13 & 22.09 \\
\hline PCTWHITE & 84.33 & 86.32 \\
\hline POPCHNG & 36.35 & 19.64 \\
\hline PRECIP & 39.22 & 35.58 \\
\hline RMEDVAL & 217.50 & 231.38 \\
\hline TAXPCAP & 228.16 & 276.73 \\
\hline
\end{tabular}


The hypothesis of equal means is rejected at the 0.01 level of significance for most variables that reflect the absolute magnitude of the study area population. This rejection also occurs for population density (POPDENS), which is positively correlated with several variables related to absolute population magnitude. The variables for which the hypothesis of equality is rejected at the 0.05 level also reflect absolute magnitude of the population or economy except for HOSPITAL, which is the number of hospital beds per 100,000 people. The regulatory structure governing bed capacity may be responsible for tying hospital capacity to population magnitude.

\subsubsection{Comparison of Renters and Home Owners}

Certainly all residents of a region should be accounted for when impacts are evaluated, although many studies are limited to home owners. Linneman (1980) suggested that a pooled model should be estimated for renters and owners, with costs converted to equivalent terms reflecting the annual total cost of shelter services. Before conducting the regression analysis, we chose to explore the ramifications of treating renters and owners as a pooled sample.

The PUMS person file was used to conduct t-tests on variable means for owners and renters to determine whether they are alike in most respects other than housing choice. Because attitudes toward risk have been found to be associated with characteristics such as education, income, sex, and age, differences in demographic composition between renters and owners could affect risk-related decisions by these two groups.

Table 5 lists the means and standard deviations for the two groups and the results of $t$-tests for the null hypothesis that the means are equal. The owner group, at an average age of 41.6 years, is significantly older than the renter group ( 34.8 vears). Owners also have significantly more experience and higher incomes, as might be expected given the age difference. These differences are apparently due more to age than to education since mean education levels are equivalent. The other major area of difference is in marital status. About $77 \%$ of owners are married, while the figure for renters is about $49 \%$. These findings suggest that treating owners and renters as separate groups in the hedonic analysis is appropriate. The differences found in mean levels of some variable;, however, do not necessarily imply similar differences in coefficients in the regression models.

\subsubsection{Determinants of Population Change}

Communities confronting the possible siting of a noxious facility in their area often are concerned that the facility will slow in-migration or increase out-migration. Either of these effects would be evidence of a market disequilibrium; however, a key assumption of the hedonic approach used in this study is that the markets are in equilibrium. To examine the implications of the assumption of equilibrium conditions, we sought to determine if population change over the previous decade was directly related to the presence of a noxious facility. 
TABLE 5 Personal Variable Means for Owners and Renters"

\begin{tabular}{|c|c|c|c|c|c|}
\hline \multirow[b]{2}{*}{ Variable } & \multicolumn{2}{|c|}{ Renters } & \multicolumn{2}{|c|}{ Owners } & \multirow[b]{2}{*}{$\mathrm{t}$} \\
\hline & Mean & $\begin{array}{l}\text { Standard } \\
\text { Deviation }\end{array}$ & Mean & $\begin{array}{l}\text { Standard } \\
\text { Deviation }\end{array}$ & \\
\hline $\mathrm{AGE}$ & 34.79 & 12.69 & 41.58 & 12.94 & $-38.68 * *$ \\
\hline EXPER & 14.08 & 13.48 & 20.84 & 13.76 & $-36.26^{* *}$ \\
\hline GRADE & 14.71 & 2.95 & 14.74 & 2.95 & -0.62 \\
\hline MARITAL & 0.49 & 0.50 & 0.77 & 0.42 & $.45 .66^{* *}$ \\
\hline SEX & 0.45 & 0.50 & 0.44 & 0.50 & 0.65 \\
\hline ANNHOURS & $1,870.49$ & 664.12 & $1,882.86$ & 678.72 & 1.36 \\
\hline TOTERINC & $11,372.67$ & $7,563.61$ & $14,209.26$ & $10,236.34$ & $-24.69^{* * *}$ \\
\hline
\end{tabular}

Although it is possible to analyze migration and commuting patterns in detail from the PUMS data, considerable effort would be required. Instead, a preliminary study of variables associated with population change was carried out on the basis of data from the County and City Data Book for the study sites. Issues associated with geographic matching of these data to study site boundaries were discussed in Section 3.3.2. The mean percentages of population change are positive for both the control and noxious facility study sites, but they differ significantly at the 0.10 level $(36 \%$ increase for the controls, $19 \%$ for areas with noxious facilities). This difference suggests the possibility of a relationship between noxious facilities and lower rates of in-migration.

Variables were selected for possible inclusion in an explanatory model of population change on the basis of their correlation with population change. The tinal model consists of 10 amenity and disamenity variables, plus median household income (MEDHSINC) and cost of living (COLINDX) controls, to which the noxious facility variables have been added to assess their effect. Estimated coefficients from the basic model, from a model with a dummy variable indicating the presence of any noxious facility, and from a model with a dummy indicating the presence of each facility type are given in Table 6.

Comparing the models indicates that the presence of noxious facilities (ANYNFAC) significantly reduces the rate of population growth. This effect does not appear to depend on the type of facility present but rather on the difference between the presence of one or more facilities and the absence of any facilities. Although none of the facility dummy variable coefficients are significant, most are negative, indicating an association with lower rates of population growth. A model incorporating facility density per 100 square miles also shows a lack of significant effects for separate facility types. Although it is not significant, the coefficient on the nuclear plant dummy was relatively large and positive, in spite of expressed aversion to living near nuclear generating plants (Lindell and Earle 1983). The fact that the 


\section{TABLE 6 Estimated Coefficients for Population} Change Models ${ }^{\text {i }}$

\begin{tabular}{|c|c|c|c|}
\hline \multirow[b]{2}{*}{ Variable } & \multicolumn{3}{|c|}{ Model Coefficients } \\
\hline & Basic & $\begin{array}{c}\text { Any Facility } \\
\text { Dummy }\end{array}$ & $\begin{array}{c}\text { Facility Type } \\
\text { Dummy }\end{array}$ \\
\hline INTERCEPT & .50 .720 & -53.578 & -88.870 \\
\hline PUNEMP & $2.961^{*}$ & 2.039 & 2.347 \\
\hline PCTWHITE & $0.904^{* *}$ & $0.904^{* *}$ & $0.850^{* * *}$ \\
\hline COLINDX & -1.251 & -1.021 & -0.768 \\
\hline MEDHSINC & $0.004^{*: k}$ & $0.004^{* * *}$ & $0.004^{* * *}$ \\
\hline TAXPCAP & $-0.055^{* k}$ & $-0.049^{*}$ & $-0.059^{*}$ \\
\hline VACANCY & $1.567^{* *}$ & $1.422^{*}$ & $1.574^{*}$ \\
\hline PUNION & .0 .339 & -0.026 & .0 .003 \\
\hline POPDENS & 0.001 & 0.001 & 0.003 \\
\hline PCTMFG & $-0.697^{*}$ & $-0.703^{* *}$ & $-0.849^{* * *}$ \\
\hline PRECIP & $0.568^{*}$ & $0.543^{*}$ & 0.477 \\
\hline TSP & -0.077 & -0.084 & .0 .099 \\
\hline PCTSUN & $1.241^{* *}$ & $1.399^{* *}$ & $1.304^{*}$ \\
\hline TEMPDIFF & $-0.916^{* *}$ & $-0.888^{* * *}$ & $-0.656^{*}$ \\
\hline ANYNFAC & & $-20.170^{*}$ & \\
\hline DNFNUP & & & 7.923 \\
\hline DNFCOP & & & -1.019 \\
\hline DNFGOP & & & -10.511 \\
\hline DNFCHM & & & -8.230 \\
\hline DNFPCR & & & -3.391 \\
\hline DNFHWS & & & 4.997 \\
\hline DNFRAC & & & .0 .929 \\
\hline DNFLNG & & & .7 .153 \\
\hline $\mathrm{R}^{2}$ & 0.5461 & 0.5750 & 0.5921 \\
\hline Adjusted $\mathrm{R}^{2}$ & 0.4617 & 0.4887 & 0.4539 \\
\hline
\end{tabular}

facility density variables are not significant does not mean that these disamenities have no effect on migration, since only total population change is examined.

Climatic, demographic, and economic characteristics have more significant influence on population change than do noxious facilities. Climatic variables affect population change substantially. Increased percentages of sunny days (PCTSUN) are an incentive to in-migration, and temperature extremes (TEMPDIFF) are a deterrent. The percentage of total employment in manufacturing industries (PCTMFG) has a significant negative influence on population growth, as does the tax rate per capita (TAXPCAP). Median household income 
(MEDHSINC) and the percentage of the population that is white (PCTWHITE) are significantly related to positive rates of population change. Signs on the remaining variable coefficients are all as expected, except percentage unemployed (PUNEMP), which is associated with population growth. This effect may have resulted from the fact that, population change is measured from 1970 to 1980 , while the value for percentage of unemployed is determined on the basis of 1980 data and may vary more over time than the other variables.

\subsection{HEDONIC REGRESSION RESULTS}

Because of the large sample size, many of the variables had t statistics with probabilities at the 0.0001 level. The explanatory power of the models, however, is not amplified by sample size. Values of $R^{2}$ for the models ranged from 0.2473 for the rental housing model to 0.6951 for the home owners wage model. It is likely that mismatches of data resulting from combining databases with somewhat different geographic units diminished the explanatory power.

Results for the owners sample estimations are presented in Tables 7 and 8 , and those for the renters sample are in Tables 9 and 10. (These tables appear near the text in which they are discussed.) Each table lists the coefficients for three alternative specifications of the noxious facility variables. Separate discussions of the findings for the owners and renters samples are followed by a comparison of the findings for control and facility variables that are common to both samples.

\subsubsection{Owners Sample Findings}

As shown in Table 7, the estimated parameters of the STRUCT variables in the owners housing value model are highly significant and consistent in sign and magnitude across model specifications. Detached housing units (DETACHED), condos (CONDO), and homes on lots larger than an acre (ACREGT1) are more highly valued, other things being equal. Central heating (HEATING) and central air-conditioning (CENTAIR) increase home value significantly, as does access to a public water system (WATER), but access to public sewers (SEWAGE) lowers value. The sign on SEWAGE is counterintuitive; perhaps this variable partially reflects an association between public sewers and smaller lot sizes. Value increases with home size as represented by BEDROOM, OTHRROOM, and BATHROOM. It is unclear why an additional bathroom should contribute more to value than an additional bedroom, but the cause may be related to the phenomenon of newer, multibath homes. Value decreases with increasing building age (BLDNGAGE) and with the length of the owner's residence there (YRMOVED).

Both of the PRICE control variables are significant across models. Cost of living (COLINDX) and median household income are directly related to higher home costs. 
TABLE 7 Comparison of Facility Measures for Owners Sample: Property Value Impacts ${ }^{a}$

\begin{tabular}{|c|c|c|c|}
\hline Variable & $\begin{array}{c}\text { Any Facility } \\
\text { Density }\end{array}$ & $\begin{array}{l}\text { Facility } \\
\text { Dummy }\end{array}$ & $\begin{array}{c}\text { Facility Type } \\
\text { Density }\end{array}$ \\
\hline INTERCEPT & $-2.101440^{*}$ & $-3.467528^{*}$ & $-3.183228^{*}$ \\
\hline DETACHED & $0.269989^{*}$ & $0.261381^{*}$ & $0.260100^{*}$ \\
\hline HEATING & $0.227683^{*}$ & $0.228019^{*}$ & $0.229210^{*}$ \\
\hline WATER & 0.005562 & 0.004351 & 0.003529 \\
\hline SEWAGE & $-0.021351^{*}$ & $-0.025054^{*}$ & $-0.027914^{*}$ \\
\hline BLDNGAGE & $-0.084508^{*}$ & $-0.085488^{*}$ & $-0.085807^{*}$ \\
\hline BEDROOM & $0.244694^{*}$ & $0.246266^{*}$ & $0.246111^{*}$ \\
\hline BATHROOM & $0.361505^{*}$ & $0.355214^{*}$ & $0.354955^{*}$ \\
\hline OTHRROOM & $0.286776^{*}$ & $0.290475^{*}$ & $0.290707^{*}$ \\
\hline ACREGT1 & $0.115339^{*}$ & $0.11 .1983^{*}$ & $0.111177^{*}$ \\
\hline CENTAIR & $0.182529^{*}$ & $0.176008^{*}$ & $0.175395^{*}$ \\
\hline CONDO & $0.202713^{*}$ & $0.191966^{*}$ & $0.191 .754^{*}$ \\
\hline YRMOVED & $-0.024752 *$ & $-0.025089^{*}$ & $-0.025038^{*}$ \\
\hline COLINDX & $0.839900^{*}$ & $1.093580^{*}$ & $1.057326^{*}$ \\
\hline MEDHSINC & $0.437343^{*}$ & $0.448553^{*}$ & $0.407297^{*}$ \\
\hline VACANCY & $.0 .082224^{*}$ & $-0.051175^{*}$ & $-0.048348^{*}$ \\
\hline CNTRLCTY & $-0.130340^{*}$ & $-0.128830^{*}$ & $-0.124592^{*}$ \\
\hline RURAL & $-0.043314^{*}$ & $-0,019898$ & $.0 .030423^{*}$ \\
\hline $\mathrm{ESC}$ & $-0.036587^{*}$ & $-0.059641^{*}$ & $-0.057220^{*}$ \\
\hline $\mathrm{SA}$ & .0 .003833 & 0.001051 & 0.003579 \\
\hline WSC & $-0.073950^{*}$ & -0.004597 & -0.011329 \\
\hline PAC & $0.230161^{*}$ & $0.095101^{*}$ & $0.096196^{*}$ \\
\hline $\mathrm{MT}$ & $0.286998^{*}$ & $0.283536^{*}$ & $0.270803^{*}$ \\
\hline WNC & 0.024426 & $0.036562^{*}$ & 0.032070 \\
\hline $\mathrm{NE}$ & $0.150542^{*}$ & -0.003334 & -0.002436 \\
\hline $\mathrm{MA}$ & $0.156617^{*}$ & $0.093340^{*}$ & $0.089097^{*}$ \\
\hline COAST & $0.078732^{*}$ & $0.107211^{*}$ & $0.111285^{*}$ \\
\hline CRIME & $0.029050^{*}$ & $0.034726^{*}$ & $0.038931^{*}$ \\
\hline PCTMFG & $-0.100092^{*}$ & $-0.070657^{*}$ & $-0.066068 *$ \\
\hline POPDENS & 0.001854 & $-0.015538^{*}$ & $-0.009934^{*}$ \\
\hline COOLDAYS & $0.053330^{*}$ & $0.087156^{*}$ & $0.083712^{*}$ \\
\hline HEATDAYS & $0.275487^{*}$ & $0.446746^{*}$ & $0.435590^{*}$ \\
\hline PCTSUN & $0.361347^{*}$ & $0.286468^{*}$ & $0.255803^{*}$ \\
\hline PRECIP & $0.063328^{*}$ & $0.051905^{*}$ & 0.038861 \\
\hline TEMPDIFF' & $.0 .514949^{*}$ & $-0.747646^{*}$ & $-0.716808^{*}$ \\
\hline TSP & $0.076985^{*}$ & $0.105603^{*}$ & $0.108171^{*}$ \\
\hline ANYNFDNS & $-0.010077^{*}$ & & \\
\hline DNF'NUP & & $-0.042560^{*}$ & \\
\hline DNFCOP & & $-0.100967^{*}$ & \\
\hline DNFGOP & & $-0.021334^{*}$ & \\
\hline
\end{tabular}


TABLE 7 (Cont'd)

\begin{tabular}{|c|c|c|c|}
\hline Variable & $\begin{array}{l}\text { Any Facility } \\
\text { Density }\end{array}$ & $\begin{array}{l}\text { Facility } \\
\text { Dummy }\end{array}$ & $\begin{array}{c}\text { Facility Type } \\
\text { Density }\end{array}$ \\
\hline DNFCHM & & $0.070821 *$ & \\
\hline DNFHWS & & $0.04 .2867^{*}$ & \\
\hline DNFPCR & & $-0.109122^{*}$ & \\
\hline DNFRAC & & $.0,024913$ & \\
\hline DNFLNG & & $0.056312^{*}$ & \\
\hline NFDNSNUP & & & $.0 .005125^{*}$ \\
\hline NFDNSCOP & & & $-0.010552^{*}$ \\
\hline NFDNSGOP & & & $-0.002346^{*}$ \\
\hline NFDNSCHM & & & $-0,008562 *$ \\
\hline NFDNSHWS & & & $0.002664^{*}$ \\
\hline NFDNSPCR & & & $.0 .010419^{*}$ \\
\hline NFDNSRAC & & & -0.001422 \\
\hline NFDNSLNG & & & $0.004807^{*}$ \\
\hline$R^{2}$ & 0.5555 & 0.5606 & 0.561 .2 \\
\hline Adjusted $\mathrm{R}^{2}$ & 0.5551 & 0,5602 & 0.5608 \\
\hline
\end{tabular}

The DISEQ variables also are generally significant and have the expected signs. Most of the regional dummies controlling for disequilibrium effects are significant, and they indicate that housing price differentials are highest in the Pacific (PAC) and IrIountain (M'T) Divisions and lowest in the East South Central (ESC) Division. Homes in both central city (CNTRLCTY) and non-SMSA (RURAL) locations have lower prices than comparable suburban housing, with a more negative price effect caused by central city location. Higher vacancy rates (VACANCY) are associated with lower house prices.

Virtually all of the AMENITYY variables are significant in the owner property models. Coefficients on both HEATDAYS and COOLDAYS are positive, while TEMPDIFF is negative, indicating a preference for hot or cold climates over those with both temperature extremes. The magnitude of the coefficient of HEATDAYS is larger than that of COOLDAYS, perhaps reflecting the higher costs of structural adaptation to cold climates. Total suspended particulates (TSP) is positive, making it likely that this variable acts as a proxy for some other production or amenity factor. CRIME also has a counterintuitive positive sign, indicating that it is probably capturing a variety of agglomeration- or consurnption-related effects. Increasing percentage of manufacturing employment (PCTMFG) and (in two models) increasing population density (POPDENS) are associated with lower home values. 
The coefficient of the variable for density of all types of facilities combined (ANYNFDNS) indicates a significant negative relationship to property values, When the facilities are modeled to test for threshold effects by using dummy variables, most of the variables indicate that the presence of any facility in the data unit decreases prices significantly. The coefficient for radioactive sites (DNFRAC) is negative and approaches significance. Unexpectedly, the signs on hazardous waste sites (DNFHWS) and liquefied natural gas facilities (DNFLNG) are positive and significant, possibly indicating an association with other types of productive activities. (However, a positive sign is not inconsistent with their classification as disamenities.) Results for the facility density specification are similar. Both sets of coefficients indicate that the net negative impacts (of perceived risks, uncompensated externalities, and positive economic stimuli) are greater for petrochemical refineries, coal-fired power plants, and chemical weapons storage sites than they are for nuclear power plants.

Table 8 lists the estimated coefficients for the owners wage models. In general, the estimated parameters for the human capital and industry (HC\&IND) control variables are highly significant, consistent with prior expectations as to sign, and stable in magnitude across alternative specifications. Annual wages are lower for females (SEX) and lower yet for married females (SEXMAR). Wages increase with experience (EXPER), but at a decreasing rate (EXPERSQ). Veteran status (VETERAN) also increases wages. Education (EDUC) and work effort (ANNHOURS) are the major determinants of annual earnings. Of the human capital characteristics, only race (WHITE) is not significant. Among occupational categories, management and professional services (MGTPROF) has the highest income differential; the highest industry differential is for mining. This latter differential may represent compensation for the high risk of death and injury among miners.

The PRICE control variable (COLINDX) is positively related to wages but is significant only in the model with all facility types combined. Median home value (HMEDVAL) is not significant, and the signs are mixed across specifications.

The coefficients of two variables in the disequilibrium (DISEQ) control category the percentage of union member's (PUNION) and the unemployment rate (PUNEMPL) - are positive and significant. Most of the regional dummies are not significant, but as a group they indicate that wages are slightly higher in western regions than in the East.

Of the AMENITY control variables, only population density (POPDENS) is significant. This variable increases wages consistently across models, indicating that it is either productive or a disamenity or both. The climatic variables are not significant.

The effect on wage rates of all types of facilities together (ANYNFDNS) is positive but not significant. The threshold measures of response to the presence of a noxious facility are generally not significant, although petrochemical refineries and LNG storage sites are associated with significantly higher wages. Results for the facility type densities are similar to those for the equivalent dummy variables. 
TABLE 8 Comparison of Facility Measures for Dwners Sample: Wage Impacts ${ }^{a}$

\begin{tabular}{|c|c|c|c|}
\hline Variable & $\begin{array}{c}\text { Any Facility } \\
\text { Density }\end{array}$ & $\begin{array}{l}\text { Factlity } \\
\text { Dummy }\end{array}$ & $\begin{array}{c}\text { Facillty Type } \\
\text { Density }\end{array}$ \\
\hline INTLRCEPT & -0.786944 & -0.557992 & -0.349740 \\
\hline SEX & $-0.238948^{*}$ & $-0.239717^{*}$ & $-0.239590^{*}$ \\
\hline MARITAL & $0.198548^{*}$ & $0.198525^{*}$ & $0.198712^{*}$ \\
\hline SEXMAR & $-0.28041 .9^{*}$ & $-0,279039^{*}$ & $-0.279086^{*}$ \\
\hline EXPER & $0.018772^{*}$ & $0.018770^{*}$ & $0.018773^{*}$ \\
\hline EXPERSQ & $-0.000310^{*}$ & $-0.000310^{*}$ & $-0.000310^{*}$ \\
\hline WHITE & -0.004758 & 0.002110 & 0.001824 \\
\hline EDDUC & $0.470622 *$ & $0.470908^{*}$ & $0.470798^{*}$ \\
\hline F'ULLTIME & $0.041547^{*}$ & $0.040888^{*}$ & $0.040961^{*}$ \\
\hline DISABLE & $-0.091925^{*}$ & $0.089738^{*}$ & $.0 .089920^{\text {* }}$ \\
\hline VETERAN & $0.054483^{*}$ & $0.054228 *$ & $0.054226^{*}$ \\
\hline ANNHOURS & $0.783033^{*}$ & $0.783635^{*}$ & $0.783485^{*}$ \\
\hline SERVICE & $0.116503^{*}$ & $0.1161 .93^{*}$ & $0.116687^{*}$ \\
\hline TECHSALE & $0.275067^{*}$ & $0.2^{\prime} / 2466^{*}$ & $0.272837^{*}$ \\
\hline OPERIAABR & (1.225106* & $0.223602^{*}$ & $0.224012^{*}$ \\
\hline PRODREPR & $0.306113^{*}$ & $0.303436^{*}$ & $0.303884^{*}$ \\
\hline MGTPROF & $0.486448^{*}$ & $0.485139^{*}$ & $0.485592^{*}$ \\
\hline AGFF & $-0,039824$ & -0.037708 & -0.037316 \\
\hline MINING & $0.181326^{*}$ & $0.185879^{*}$ & $0.184855^{*}$ \\
\hline CONSTR & 0.019410 & 0.019540 & 0.019629 \\
\hline TRANSCU & $0.093031^{*}$ & $0.093432 *$ & $0.093416^{*}$ \\
\hline SALES & $-0.165945^{*}$ & $-0.166883^{*}$ & $-0.166735^{*}$ \\
\hline FINIRE & $-0.044885^{*}$ & $-0.047710^{*}$ & $-0.047766^{*}$ \\
\hline ISERVICE & $-0.168884^{*}$ & $-0.170592 *$ & $-0.170503^{*}$ \\
\hline PROFSERV & $-0.081524^{*}$ & $.0 .082799 *$ & $.0 .083030^{*}$ \\
\hline ENTERREC & $-0.246775^{*}$ & $-0.249531^{*}$ & $-0.249277^{*}$ \\
\hline PADMIN & -0.012537 & -0.015425 & -0.015461 \\
\hline COLINDX & $0.381376^{*}$ & 0.211037 & 0.196373 \\
\hline HMEDVAL & -0.015510 & 0.068934 & 0.077410 \\
\hline PUNEMPL & 0.026532 & $0.054704^{*}$ & $0.050685^{*}$ \\
\hline PUNION & $0.087014^{*}$ & $0.090314^{*}$ & $0.091723^{*}$ \\
\hline ESC & -0.051183 & -0.047878 & -0.043028 \\
\hline $\mathrm{SA}$ & 0.004010 & 0.017080 & 0.016207 \\
\hline WSC & 0.037508 & 0.037719 & 0.041794 \\
\hline PAC & 0.030835 & -0.011085 & .0 .016494 \\
\hline $\mathrm{MT}$ & 0.023765 & 0.033054 & 0.034647 \\
\hline WNC & 0.035751 & $0.055110^{*}$ & $0.051949^{*}$ \\
\hline $\mathrm{NE}$ & $-0.099630^{*}$ & $-0.082559^{*}$ & $-0.085751^{*}$ \\
\hline $\mathrm{MA}$ & $-0.053468^{*}$ & $-0.058136^{*}$ & $-0.060435^{*}$ \\
\hline COAST & 0.021059 & 0.019604 & 0.022083 \\
\hline CRIME & 0.025189 & 0.010792 & 0.008517 \\
\hline PCTMFG & -0.000961 & 0.014802 & 0.015062 \\
\hline
\end{tabular}


TABLE 8 (Cont'd)

\begin{tabular}{|c|c|c|c|}
\hline Variable & $\begin{array}{c}\text { Any Facility } \\
\text { Density }\end{array}$ & $\begin{array}{l}\text { Facillty } \\
\text { Dummy }\end{array}$ & $\begin{array}{c}\text { Facility Type } \\
\text { Density }\end{array}$ \\
\hline POPDENS & $0.022699^{*}$ & $0.016963^{*}$ & $0.014296^{*}$ \\
\hline COOLDAYS & 0.007267 & $-0,003275$ & -0.002239 \\
\hline HEATDAYS & 0,037143 & 0.007729 & 0.011118 \\
\hline PCTSUN & 0.075793 & 0.011724 & -0.000071410 \\
\hline PRECIP & -0.021615 & -0.020487 & -0.021643 \\
\hline TEMPDIFF & -0.037535 & -0.024204 & -0.028503 \\
\hline TSP & 0.006132 & 0,020768 & 0.021955 \\
\hline ANYNFDNS & 0.001729 & & \\
\hline DNFNUP & & 0.0101 .90 & \\
\hline DNFCOP & & 0.007811 & \\
\hline DNFGOP & & 0.015336 & \\
\hline DNFCHM & & 0.009218 & \\
\hline DNFHWS & & -0.012408 & \\
\hline DNFPCR & & $0.049565^{*}$ & \\
\hline DNFRAC & & -0.006335 & \\
\hline DNFLNG & & $0.058260^{*}$ & \\
\hline NFDNSNUP & & & 0.001487 \\
\hline NFDNSCOP & & & 0.001312 \\
\hline NFDNSGOP & & & 0.001709 \\
\hline NFDNSCHM & & & 0.000902 \\
\hline NFDNSHWS & & & -0.000790 \\
\hline NFDNSPCR & & & $0.005648^{*}$ \\
\hline NFDNSRAC & & & -0.000930 \\
\hline NFUNSLNG & & & $0.004917^{*}$ \\
\hline$R^{2}$ & 0.6942 & 0.6951 & 0.6951 \\
\hline Adjusted $\mathrm{R}^{2}$ & 0.6934 & 0.6942 & 0.6942 \\
\hline
\end{tabular}

$a *$ = significant at the $>0.01$ level.

\subsubsection{Renters Sample Findings}

In the renters housing value model shown in Table 9, the estimated parameters of the STRUCT variables are generally highly significant and consistent in sign and magnitude across model specifications. Only WATER and SEWAGE are not significant. STRUCT variables that are included in both the owners and renters housing models are identical in sign in both sets of models. In contrast to the owners models, in the renters model, an additional bathroom contributes less to value than an additional bedroom or other room (OTHRROOM). Rents decrease significantly as the size of the building (UNITS1) increases.

Of the PRICE control variables, only cost of living (COLINDX) is significant across models. It is positively related to higher rents. Except for the regional dummies, the DISEQ 
TABLE 9 Comparison of Facility Measures for Renters Sample: Property Value Impacts ${ }^{a}$

\begin{tabular}{|c|c|c|c|}
\hline Variable & $\begin{array}{l}\text { Any Facility } \\
\text { Density }\end{array}$ & $\begin{array}{l}\text { Facility } \\
\text { Dummy }\end{array}$ & $\begin{array}{c}\text { Facility Type } \\
\text { Density }\end{array}$ \\
\hline INTERCEPT & $6.078279^{*}$ & $5.677740^{* *}$ & $5.590235^{*}$ \\
\hline DETACHED & $0.109602 *$ & $0.109000^{*}$ & $0.109177^{*}$ \\
\hline HEATTNG & $0.022024^{* k}$ & $0.021245^{*}$ & $0.021503^{*}$ \\
\hline WATER & 0.026571 & 0.026931 & 0.027176 \\
\hline SEWAGE & -0.013824 & -0.014358 & -0.014847 \\
\hline BLDNGAGE & $-0.028845^{*}$ & $-0.028409^{* *}$ & $-0.028490^{* k}$ \\
\hline BEDROOM & $0.136095^{*}$ & $0.136635^{*}$ & $0.136397^{*}$ \\
\hline BATHROOM & $0.024541^{*}$ & $0.022179^{*}$ & $0.022170^{*}$ \\
\hline OTHRROOM & $0.080596^{*}$ & $0.082603^{*}$ & $0.082669^{*}$ \\
\hline CENTAIR & $0.100905^{*}$ & $0.101962^{* *}$ & $0.101342^{*}$ \\
\hline UNITS1 & $.0 .007987^{*}$ & $-0.008076^{*}$ & $-0.008088^{*}$ \\
\hline YRRAOVED & $-0.024920^{*}$ & $-0.025362^{*}$ & $-0.025420^{*}$ \\
\hline COLINDX & $0.405199^{* *}$ & $0.520303^{*}$ & $0.516468^{*}$ \\
\hline MEDHSINC & 0.002642 & 0.009968 & 0.027606 \\
\hline VACANCY & 0.035921 & $-1) .021926$ & -0.019620 \\
\hline CNTRLCTY & 0.001978 & 0.000530 & 0.000643 \\
\hline RURAL & .0 .005634 & 0.007162 & 0.006678 \\
\hline ESC & -0.002329 & .0 .022601 & -0.022938 \\
\hline$S A$ & -0.004876 & -0.017051 & -0.024358 \\
\hline WSC & .0 .013407 & .004980 & .0 .010051 \\
\hline $\mathrm{PAC}$ & 0.033363 & -0.037915 & .0 .025303 \\
\hline $\mathrm{MT}$ & $0.0 ; 1820^{* k}$ & 0.038364 * & $0.040403^{*}$ \\
\hline WNC & $0.028959^{* *}$ & $0.051254^{*}$ & $0.047804^{: k}$ \\
\hline $\mathrm{NE}$ & $0.100373^{*}$ & $0.067286^{k}$ & $0.067568^{*}{ }^{*}$ \\
\hline $\mathrm{MA}$ & $0.084143^{*}$ & $0.0522283^{*}$ & $0.053164 *$ \\
\hline COAST & 0.018290 & $0.028730^{*}$ & 0.026170 \\
\hline CRIME & 0.006740 & 0.006010 & 0.007658 \\
\hline PCTMFG & 0.001172 & 0.009179 & 0.009878 \\
\hline POPDE & $0.011082^{*}$ & $0.00885 .3^{*}$ & $0.008491^{*}$ \\
\hline COOLDAYS & -0.009709 & -0.006426 & -0.008099 \\
\hline HEATDAYS & $.0 .037317^{*}$ & -0.007631 & .0 .015910 \\
\hline PCTSUN & 0.032627 & -0.017538 & -0.015543 \\
\hline PRECIP & -0.010423 & .0 .024514 & -0.019247 \\
\hline TEMPDIFF & $0.0240^{\prime} 78$ & -0.047504 & -0.033619 \\
\hline TSP & $0.019347^{*}$ & 0.003320 & 0.000031874 \\
\hline ANYNFDNS & .0 .002760 & & \\
\hline DNFNUP & & $0.02441 .1^{*}$ & \\
\hline DNFCOP & & $.0 .017299^{*}$ & \\
\hline DNFGOP & & -0.016139 & \\
\hline DNFCHM & & 0.013768 & \\
\hline
\end{tabular}


TABLE 9 (Cont'd)

\begin{tabular}{|c|c|c|c|}
\hline Variable & $\begin{array}{l}\text { Any Facility } \\
\text { Density }\end{array}$ & $\begin{array}{l}\text { Facility } \\
\text { Dummy }\end{array}$ & $\begin{array}{c}\text { Facility Type } \\
\text { Density }\end{array}$ \\
\hline DNFHWS & & 0.003618 & \\
\hline DNFPCR & & 0.003489 & \\
\hline DNFRAC & & $0.022921^{*}$ & \\
\hline DNFLNG & & $0.042888^{*}$ & \\
\hline NFDNSNUP & & & $0.002368^{*}$ \\
\hline NFDNSCOP & & & -0.001403 \\
\hline NFDNSGOP & & & -0.001212 \\
\hline NFDNSCHM & & & 0.001470 \\
\hline NFDNSHWS & & & 0.000377 \\
\hline NFDNSPCR & & & 0.000010739 \\
\hline NFDNSRAC & & & $0.002055^{*}$ \\
\hline NFDNSLNG & & & $0.003965^{*}$ \\
\hline $\mathrm{R}^{2}$ & 0.2473 & 0.2510 & 0.2508 \\
\hline Adjusted $R^{2}$ & 0.2452 & 0.2484 & 0.2482 \\
\hline
\end{tabular}

a $: *$ significant at the $>0.01$ level.

variables are not significant. Higher vacancy rates (VACANCY) are associated with lower rental prices, and the coefficients are marginally significant. Regional dummies controlling for northerm areis with substantial heating requirements are significant and positive.

Of the AMENITY variables, only population density (POPDENS) is significant across all specifications. Coefficients of both HEATDAYS and COOLDAYS are negative, indicating a counterintuitive inverse relationship between space conditioning requirements and rents. Signs on several of the amenity variables are mixed across models.

The coefficient of the variable for density of all types of facilities combined (ANYNFDNS) indicates a significant negative effect on property values. When the facilities are modeled to test for threshold effects by using dummy variables, only coal-fired power plants have a significant negative price impact. The coefficients for nuclear power plants (DNFNUP), radioactive sites (DNFRAC), and LNG storage sites (DNFLNG) are positive and significant. (This finding is not inconsistent with their classification as disamenities.") Results for the facility density specification are similar.

Table 10 lists the estimated cuefficients for the renters wage models. The estimated parameters for the human capital and industry (HC\&IND) control variables are generally

\footnotetext{
*As Roback (1982) demonstrated, it is the net impact of disamenities on both labor and land markets that is negative.
} 
TABLE 10 Comparison of Facility Measures for Renters Sample: Wage Impacts ${ }^{2}$

\begin{tabular}{|c|c|c|c|}
\hline Variable & $\begin{array}{c}\text { Any Facility } \\
\text { Density }\end{array}$ & $\begin{array}{l}\text { Facility } \\
\text { Dummy }\end{array}$ & $\begin{array}{c}\text { Facility Type } \\
\text { Density }\end{array}$ \\
\hline INTERCEPT & 0.084235 & 0.116022 & 0.201497 \\
\hline SEX & $-0.231043^{*}$ & $-0.231490^{*}$ & $-0.231546^{*}$ \\
\hline MARITAL & $0.046448^{*}$ & $0.046375^{*}$ & $0.046958^{*}$ \\
\hline SEXMAR & $-0.159832^{*}$ & $-0.161268^{*}$ & $-0.161967^{*}$ \\
\hline EXPER & $0.017716^{*}$ & $0.017694^{*}$ & $0.017741^{*}$ \\
\hline EXPERSQ & $-0.000278^{*}$ & $-0.000279^{*}$ & $-0.000280^{*}$ \\
\hline WHITE & 0.026858 & $0.038685^{*}$ & $0.037739^{*}$ \\
\hline EDUC & $0.478823^{*}$ & $0.466598^{*}$ & $0.467474^{*}$ \\
\hline FULLTIME & -0.020481 & -0.019438 & -0.0194 .31 \\
\hline DISABLE & $-0.150147^{*}$ & $-0.152049^{*}$ & $-0.152043^{*}$ \\
\hline VETERAN & -0.006331 & -0.008477 & -0.008425 \\
\hline ANNHOURS & $0.751025^{*}$ & $0.750054^{*}$ & $0.7498: 32^{*}$ \\
\hline SERVICE & 0.084837 & 0.096476 & 0.101039 \\
\hline TECHSALE & 0. $220375^{*}$ & $0.226222^{k}$ & $0.229497^{*}$ \\
\hline OPERLABR & 0.153889 & $0.159991^{*}$ & $0.163037^{*}$ \\
\hline PRODREPR & $0.258920^{*}$ & $0.263518^{*}$ & $0.266935^{*}$ \\
\hline MGTPROF & $0.373692^{*}$ & $0.381837^{*}$ & $0.385095^{*}$ \\
\hline $\mathrm{AGFF}$ & -0.026680 & -0.027486 & -0.024243 \\
\hline MINING & $0.300429^{*}$ & $0.326764^{*}$ & $0.327927^{*}$ \\
\hline CONSTR & 0.045200 & 0.047632 & 0.048906 \\
\hline TRANSCU & $0.151882^{*}$ & $0.151157^{*}$ & $0.151100^{*}$ \\
\hline SALES & $0.147645^{*}$ & $-0.146419^{*}$ & $-0.146962^{*}$ \\
\hline FINIRE & .0 .063638 & $-0.066290^{*}$ & $-0.066730^{*}$ \\
\hline ISERVICE & $-0.110847^{*}$ & $-0.114079^{*}$ & $-0.114250^{k}$ \\
\hline PROFSERV & $-0.064926^{*}$ & $-0.064081^{*}$ & $-0.064771^{*}$ \\
\hline ENTERREC & $-0.219001^{*}$ & $-0.218013^{*}$ & $-0.218544^{* k}$ \\
\hline PADMIN & 0.034361 & 0.031469 & 0.030684 \\
\hline COLINDX & 0.500071 & 1.012605 & 1.078829 \\
\hline RMEDVAL & -0.233001 & -0.747432 & -0.777097 \\
\hline PUNEMPL & -0.010082 & -0.094905 & -0.101868 \\
\hline PUNION & 0.114351 & $0.2375 .15^{*}$ & $0.260530^{*}$ \\
\hline ESC & -0.021637 & -0.030006 & -0.018953 \\
\hline SA & -0.036897 & 0.010682 & 0.012082 \\
\hline WSC & 0.021936 & -0.008658 & -0.005809 \\
\hline $\mathrm{PAC}$ & 0.030737 & -0.160408 & -0.154863 \\
\hline $\mathrm{MT}$ & -0.059716 & -0.022526 & -0.004367 \\
\hline $\mathrm{WNC}$ & .0 .019235 & 0.046441 & 0.053165 \\
\hline $\mathrm{NE}$ & -0.024707 & $-0.097363^{*}$ & $-0.100902^{*}$ \\
\hline $\mathrm{MA}$ & -0.021594 & -0.080188 & -0.085318 \\
\hline COAST & 0.017906 & 0.109380 & 0.117174 \\
\hline CRIME & 0.051348 & 0.081323 & 0.082181 \\
\hline PCTMFG & 0.023608 & $0.061526^{*}$ & $0.067428^{*}$ \\
\hline POPDENS & 0.003619 & 0.001474 & 0.000869 \\
\hline
\end{tabular}


TABLE 10 (Cont'd)

\begin{tabular}{lccc}
\hline \multicolumn{1}{c}{ Variable } & $\begin{array}{c}\text { Any Facility } \\
\text { Density }\end{array}$ & $\begin{array}{c}\text { Facility } \\
\text { Dummy }\end{array}$ & $\begin{array}{c}\text { Facility Type } \\
\text { Density }\end{array}$ \\
\hline COOLDAYS & -0.012811 & -0.020498 & -0.023556 \\
HEATDAYS & -0.051988 & -0.023749 & -0.035275 \\
PCTSUN & 0.100912 & 0.192746 & 0.221277 \\
PRECIP & -0.038598 & -0.141509 & $-0.149293^{*}$ \\
TEMPDIFF & 0.084574 & -0.059929 & -0.039118 \\
TSP & -0.004384 & 0.053625 & 0.047138 \\
ANYNFDNS & 0.004541 & & \\
DNFNUP & & $0.102946^{*}$ & \\
DNFCOP & & -0.033063 & \\
DNFGOP & & -0.040982 & \\
DNFCHM & & 0.000438 & \\
DNFHWS & & -0.003153 & \\
DNFPCR & & $0.137839^{*}$ & \\
DNFRAC & & 0.065504 & \\
DNFLNG & & $0.128273^{*}$ & \\
NFDNSNUP & & & $0.011231^{*}$ \\
NFDNSCOP & & & -0.002981 \\
NFDNSGOP & & & -0.004611 \\
NFDNSCHM & & & -0.001339 \\
NFDNSHWS & & & -0.000642 \\
NFDNSPCR & & 0.5843 & $0.012978^{*}$ \\
NFDNSRAC & & & 0.005247 \\
NFDNSLNG & & & $0.011743^{*}$ \\
R ${ }^{2}$ & & & $0.5838 \ldots \ldots \ldots$ \\
Adjusted R & & & 0.5805 \\
\hline
\end{tabular}

$a *$ significant at the $>0.01$ level.

highly significant, consistent with prior expectations as to sign, and stable in magnitude across alternative specifications. The coefficients for SEX, EXPER, EXPERSQ, EDUC, and ANNHOURS are comparable in magnitude to those in the owners sample models. Unlike the owners models, racial status (WHITE) is significantly and positively associated with income in the renters model. Veteran status (VETERAN) and full-time employment. (FULLTIME) have the opposite effect but are not significant. Education (EDUC) and work effort (ANNHOURS) are the major determinants of annual earnings. Signs on the occupational and industry categories are identical to those found in the owners models.

The PRICE control variable (COLINDX) is positively related to wages but not significant. Median rental value (RMEDVAL) is not significant and is inversely related to wages. 
Most of the coefficients of the disequilibrium (DISEQ) control variables are not significant. However, the percentage of union members (PUNION) is positive and significant in two models. Most of the regional dummies are not significant, except those for the Northeast (NE), which are negative and significant, as they also are in the owners models.

Among the AMENITY control variables, only the percentage of total employment in manufacturing (PCTMFG) is significant, and it is positively related to wages. The climatic variables are not significant, except for annual precipitation rate (PRECIP) in the facility density specification.

The effect on wage rates of all types of facilities together (ANYNFDNS) is positive and not significant. The threshold measures of response to the presence of a noxious facility are generally not significant, although nuclear power plants (DNFNUP), petrochemical refineries (DNFPCR), and LNG storage sites (DNFLNG) are associated with significantly higher wages. Results for the facility type densities are similar to those for the equivalent facility type dummy variables.

\subsubsection{Comparison of Estimates for Selected Control and Facility Variables}

Estimating model parameters with TSLS should produce equivalent estimates for each variable from the property and wage models. Confirmatory estimates would be opposite in sign. Coefficients from the models for both owners and renters are shown in Table 11. These estimates were taken from the facility dummy variable specification and represent the variables common to all four models.

When the two owners models are compared, several variables with significant, confirmatory parameter estimates can be classified unambiguously as amenities or disamenities. The first of these is population density (POPDENS), which lowers property values and increases wages, indicating that home owners perceive increasing density as a disamenity. PCTSUN has the opposite effect, indicating it is an amenity. Similarly, the regional variables indicate that the East South Central (ESC) Division is negatively valued, while the Middle Atlantic (MA) is positively valued.

In addition, the findings for some variables are unambiguous but not as strong, in that the estimated signs are opposite but one parameter is not significant. In this category, crime rate (CRIME) and cooling-degree-days (COOLDAYS) are vaiued as amenities, a clear indication that CRIME is capturing some other effect, perhaps access to the city center. Conversely, the percentage of employment in manufacturing (PCTMFG) is a disimenity. Location in the Mountain states (MT) is positively valued and in the Northeast (NE) is negatively valued.

Home owners clearly consider the presence of a refinery (DNFPCR) a disamenity, a finding that is slightly less strong for nuclear plants (DNFNUP), coal-fired plants (DNFCOP), gas- and oil-fired plants (DNFGOP), and chemical weapons storage sites (DNFCHM). The only facility type that is unambiguously valued positively is the hazardous waste category 
TABLE 11 Comparison of Amenity Variables in Facility Dummy Model Specification"

\begin{tabular}{|c|c|c|c|c|}
\hline Variable & $\begin{array}{c}\text { Owners } \\
\text { Property Model } \\
\end{array}$ & $\begin{array}{c}\text { Owners } \\
\text { Wage Model }\end{array}$ & $\begin{array}{c}\text { Renters } \\
\text { Property Model }\end{array}$ & $\begin{array}{c}\text { Renters } \\
\text { Wage Model } \\
\end{array}$ \\
\hline COLINDX & $1.093580^{*}$ & 0211037 & $0.520303^{*}$ & 1.012665 \\
\hline $\mathrm{ESC}$ & $.0 .059641^{*}$ & $0.016963^{*}$ & -0.022601 & -0.030006 \\
\hline $\mathrm{SA}$ & 0.001051 & -0.047878 & -0.017051 & 0.010682 \\
\hline WSC & .0 .004597 & 0.017080 & -0.004980 & -0.008658 \\
\hline $\mathrm{PAC}$ & $0.095101^{*}$ & 0.037719 & -0.037915 & -0.160408 \\
\hline $\mathrm{MT}$ & $0.283536^{*}$ & -0.011085 & $0.038364^{*}$ & -0.022526 \\
\hline WNC & $0.036662 *$ & 0.033054 & $0.051254^{*}: k$ & 0.046441 \\
\hline $\mathrm{NE}$ & .0 .003334 & $0.055110^{*}$ & $0.067286^{*}$ & $-0.097363^{*}$ \\
\hline MA & $0.093340^{*}$ & $-0.058136^{*}$ & $0.052223^{*}$ & -0.080188 \\
\hline COAST & $0.107211^{*}$ & 0.019604 & $0.028730^{*}$ & 0.109380 \\
\hline CRIME & $0.034726^{*}$ & -0.024204 & 0.006010 & 0.081323 \\
\hline PCTMFG & $0.070657^{*}$ & 0.014802 & 0.009179 & $0.061526^{k}$ \\
\hline POPDENS & $-0.015538^{*}$ & $0.783635^{*}$ & $0.008853^{*}$ & 0.001474 \\
\hline COOLDAYS & $0.087156^{*}$ & -0.003275 & .0 .006426 & -0.020498 \\
\hline HEATDAYS & $0.446746^{*}$ & 0.007729 & -0.007631 & .0 .023749 \\
\hline PCTSUN & $0.286468^{*}$ & $-0.082559^{*}$ & -0.017538 & 0.192746 \\
\hline PRECIP & $0.051905^{*}$ & 0.011724 & -0.024514 & -0.141509 \\
\hline TEMPDIFF & $-0.747646^{*}$ & -0.020487 & -0.047504 & -0.059929 \\
\hline TSP & $0.105603^{*}$ & 0.020768 & 0.003320 & 0.053625 \\
\hline DNFNUP & $-0.042560^{*}$ & 0.010190 & $0.024411^{*}$ & $0.102946^{*}$ \\
\hline DNFCOP & $-0.100967^{*}$ & 0.007811 & $-0.017299^{*}$ & .0 .033063 \\
\hline DNFGOP & $-0.021334^{*}$ & 0.015336 & -0.016139 & -0.040982 \\
\hline DNFCHM & $-0.070821^{*}$ & 0.009218 & 0.013768 & 0.000438 \\
\hline DNFHWS & $0.042867^{*}$ & -0.006335 & 0.003618 & -10.003153 \\
\hline DNFPCR & $-0.109122^{*}$ & $0.058260^{*}$ & 0.003489 & $0.137839^{*}$ \\
\hline DNFRAC & -0.024913 & -0.012408 & $0.022921^{*}$ & 0.065504 \\
\hline DNFLNG & $0.056312^{*}$ & $0.049565^{*}$ & $0.042888^{*}$ & $0.128273^{*}$ \\
\hline $\mathrm{R}^{2}$ & 0.5626 & 0.6951 & 0.2510 & 0.5843 \\
\hline Adjusted $R^{2}$ & 0.5602 & 0.6942 & 0.2484 & 0.5811 \\
\hline
\end{tabular}

${ }^{*} *$ significant at the $>0.01$ level.

(DNFHWS), which includes Superfund and low-level radioactive waste disposal sites. This finding may reflect either lack of public information about these sites in 1980, their association with productive activities, or both.

The findings for renters are much less definitive. None of the variables, except Northeast Region location, are opposite in sign and significant. In the case of the Northeast Region, however, the findings conflicted with those for owners in that the signs are opposite. Among the other control variables, only the estimates for the Mountain (MT) and Middle Atlantic (MA) Divisions clearly confirm findings in the owners models. Results for the facility variables are also inconclusive. 


\section{CONCLUSIONS AND RECOMMENDATIONS}

We set out to ascertain whether there are any measurable economic impacts that are clearly attributable to the presence of noxious facilities. By using a cross-section of sites, with and without noxious facilities, that represent a broad range of location characteristics, we determined that significant negaive effects on property and wage markets are associated with some types of facilities. It is unclear, however, to what extent these effects are due to negative perceptions. The economic impacts estimated in this study are net values of both positive or negative perception-based impacts and direct or indirect economic impacts due to the presence of, or activities at, a facility. However, the finding of significant net negative impacts even though a facility stimulates the local economy is an indication that substantial perception-based negative impacts are associated with the facility. The perception of risk or nuisance effects from such a facility results in reduced demand for residences and reduced willingness to accept employment in the region that more than offset the employment and income generated by the facility.

Previous studies of facility impacts generally have identified gradients of impacts that attenuate within a radius of a mile or two. Very few studies have found impacts extending more than five miles from a facility. In contrast, this analysis identifies effects that significantly influence property values and wages over broad regions. In sparsely populated areas, the data units cover very large geographical areas. Although in many cases the coefficients are small in absolute terms, the fact that they represent averages per residence or per employee for such large areas implies that the total dollar value may be quite large. These findings do not negate the possible existence of fairly steep impact gradients near facilities.

Overall, the estimated hedonic models have produced reasonable results. Coefficient magnitude can be evaluated easily for housing and individual attributes, and the estimates are reasonable, consistent, and stable across specifications. Results for the amenity variables are less consistent, and it is likely that some of the major area characteristics that affect location choices have been omitted. Further effort to augment the database or to try an approach such as factor analysis to represent amenity types is indicated. Results for facility variables are stable and consistent across models for some facility categories but not for others.

Regression analysis was used to examine the determinants of variations in the rate of population growth at the noxious facility sites. Relatively warm, sunny, temperate climate , is associated with higher levels of population growth, while slower growth is found in areas with greater temperature extremes. In addition, the percentage of total employment in manufacturing and the level of taxation per capita are inversely related to population growth, while there is a direct relationship between population growth and the percentage of the population that is white. The presence of any noxious facility has a negative, significant, and relatively large impact on population change, although none of the facility types, considered 
individually, has a significant effect. Nuclear power plants, however, have the largest positive coefficient, indicating that they are associated with high rates of population growth.

The signs and magnitudes of some amenity and facility variables differ between the renter and owner markets. These differences may well reflect underlying differences in preferences and in risk evaluation. More of these variables are highly significant in the owners model, and the coefficients of the facility variables generally constitute a larger portion of mean home value. These effects may be related to differences between owners and renters in age and income. Psychological research on risk preferences has shown such demographic characteristics to be important (Jenkins-Smith et al. 1991; Mushkatel et al. $1990)$.

Three facility variable specifications are examined. The first, combined density of all types of facilities, has a clearly negative impact on both owners and renters. It is associated with higher wage compensation and significantly lower housing values. Results of the dummy variable specification by facility type are more difficult to interpret. It is apparent from the facility dummy variable specification that the presence of even one facility in an area has a significantly negative impact on owner-occupied housing values. This impact indicates that a threshold effect occurs as markets adjust to the location of noxious facilities. Because the analysis is conducted on a regional (rather than neighborhood) basis, it is clear that the presence of one representative of a facility category is sufficient to affect property values over a relatively large area. Estimates from the income models generally support this conclusion, although most of the coefficients are not significant. Rental housing values, in contrast, tend to increase if a noxious facility is present. Results of the facility density specification are similar with regard to the impact of each facility type. In general, property values decline and incomes rise with increasing facility density.

In both the dummy and density variable specifications, the facilities with the most unambiguously negative impact are refineries. This finding is reasonable vecause in spite of the positive economic stimulus of refineries, they are associated with documented negative health effects in neighboring populations, with air pollution, and with the risk of explosion, and they also have an unaesthetic appearance. Next most negative are coal-fired power plants; gas- and oil-fired plants follow. The finding that LNG storage sites and hazardous waste sites have positive impacts on property values is more problematic. Explosion risks are associated with LNG facilities, and groundwater contamination is associated with some hazardous waste sites. The finding that property values are higher in areas with such facilities than in areas without them is inconsistent with theory because neither type of facility generates many jobs. It is possible that variations in economic infrastructure have been partially captured by these facility variables.

The preliminary results for nuclear facilities are somewhat mixed. The regression results for nuclear generating plants appear to contradict previous findings regarding lack 
of negative property value impacts (e.g., Gamble et al. 1978); however, troubling aspects of the findings keep us from reaching strong conclusions. For instance, although the offect of nuclear generators on owner-occupied home values is statistically significant and negative, the effect on the rental housing market is significant and positive. If strong negative effects occur in the owned housing market, the income results for owners should also be significant. However, only renter's' incomes are affected significantly. The results for FUSRAP (radioactively contaminated) sites for owners' home values and renters' incomes reinforce conclusions that may be drawn from the results for nuclear generating plant sites, but results in the other two models are opposite and do not confirm these conclusions.

Overall, the results of this exploratory research indicate that hedonic methods are a valuable tool for estimating the impacts of noxious facilities on local economies. Such facilities appear to depress area-wide values of owner-occupied housing significantly and, in some cases, to increase area wage rates significantly. The implications of these findings indicate that a study of a larger sample of geographical units certainly is warranted. The inclusion of categories of industrial facilities (besides refineries) that have substantial environmental impacts also would improve the applicability of the findings to a variety of contexts. A method of extending the analysis to examine the impacts of noxious facilities by explicitly incorporating the equilibrating effects of migration is described in a report by Nieves and Clark (1991).

\footnotetext{
"Several differencus between our analysis and previous analyses could explain the different findings. Our analysis is a broad cross-sectional study rather than a time-series analysis looking at values at a single site before and after a specified event. In addition to the basic difference in approach, none of the previous studies controlled for amenities or included the rental market. Only a few of the previous studies used control sites.
} 


\section{REFERENCES}

American Chamber of Commerce Researchers Association, 1980, Inter-City Cost of Living Indicators, Fourth Quarter Index Report.

Beeson, P.E., and R.W. Eberts, 1989, Identifying Productivity and Amenity Effects in Interurban Wage Differentials, Review of Economics and Statistics, 71:443-452.

Blomquist, G.C., M.C. Berger, and J.P. Hoehn, 1988, New Estimates of Quality of Life in Urban Areas, American Economic Review, 78(1):89-10?.

Butler, R.V., 1980, Cross-Sectional Variation in the Hedonic Relationship for Urban Housing Markets, J. Regional Science, 20(4):439-453.

Clark, D.E., and J.C. Cosgrove, 1990, Hedonic Prices, Identification, and the Demand for Public Safety, J. Regional Science, 30(1):105-121, Feb.

Clark, D.E., and J.R. Kahn, 1989, The Two-Stage Hedonic Wage Approach: A Methodology for the Valuation of Environmental Amenities, J. Environmental Economics and Management, 16:106-120.

Gamble, H.B., R.H. Downing, and O.H. Sauerlender, 1978, Effects of Nuclear Power Plants on Community Growth and Residential Property Values, U.S. Nuclear Regulatory Commission Report NUREG/CR-0454, Washington, D.C.

Garvey, D.B., S.B. Moser, and D.G. Streets, 1982, In Pursuit of Clean Air: A Data Book of Problems and Strategies at the State Level, 1982 Update, Argonne National Laboratory Report ANL/EES-TM-212, Aug.

Graves, P.E., and T.A. Knapp, 1985, Hedonic Analysis in a Spatial Context: Theoretical Problems in Valuing Locaition-Specific Amenities, Economic Record, 737-743, Dec.

Hageman, R.K., 1981, Nuclear Waste Disposal: Potential Property Value Impacts, Natural Resources J., 21:789-810, Oct.

Haurin, D.R., 1980, The Regional Distribution of Population, Migration, and Climate, Quarterly J. Economics, 95:293-308, Sept.

Henderson, J.V., 1982, Evaluating Consumer Amenities and Interregional Welfare Differences, J. Urban Economics, 11:32-59.

Hoehn, J.P., M.C. Berger, and G.C. Blomquist, 1987, A Hedonic Model of Interregional Wages, Rents, and Amenity Values, J. Regional Science, 27(4):605-620. 
Jenkins-Smith, H.C., J.L. Espey, A.A. Rouse, and D.H. Molund, 1991, Perceptions of Risks in the Management of Nuclear Wastes: Mapping Elite and Mass Beliefi and Attitudes, Sandia National Laboratories Report SAND90-7002, Albuquer'que, N.M.

Kokkelenberg, E.C., and D.R. Sockell, 1985, Union Membership in the United States: 1973. 1981, Industrial and Labor Relations Review, 38(4):497-543, July.

Lindell, M.K., and T.C. Earle, 1983, How Close is Close Enough: Public Perceptions of the Risks of Industrial Facilities, Risk Analysis, 3(4):245-252.

Linneman, P., 1.980, Some Empirical Results on the Nature of the Hedonic Price Function for the Urban Housing Market, J. Urban Economics, 8:47-68.

Mountain West Research, 1989, Yucoa Mountain Socioeconomic Project Preliminary Findings: 1989 Nevada State Telephone Survey, Las Vegas, Nev.

Mushkatel, A.H., K.D. Pijawka, and M. Dantico, 1990, Risk-Induced Social lmpants: The Eiffects of the Proposed Nuclear Waste Repository on Residents of the Las Vegas Metropolitan Area, NWPO-SE-032-90, State of Nevada, Nuclear Waste Project Office, Carson City, Nev.

Nelson, J.P., 1978, Residential Choice, Hedonic Prices, and the Demand for Air Quality, j. Urban Economics, 5:357-369.

Nieves, L.A., and D.E. Clark, 1991, Determining Perception-Based Impacts of Noxious Facilities on Wage Rates and Property Values, Argorme National Laboratory Report ANL/EAIS/TM-65, July.

Nieves, L.A., D.R. Wernette, R.C. Hemphill, S. Mohiudden, and J. Corso, 1990, Identification and Estimation of Socioeconomic Impacts Resulting from Perceived Risks and Changing Images: An Annotated Bibliography, Argonne National Laboratory Report ANL/EAIS/IMI-24, Feb.

Nieves, L.A., D.E. Clark, and D.R. Wernett, 1991, Update of Identification and Estimation of Socioeconomic Impacts Resulting from Perceived Risks and Changing Images: An Annotated Bibliography', Argonne National Laboratory Report ANL/EAIS/T'M-XX, Month.

NOAA, undated, Comparative Climatic: Data for the United States through 1987, National Oceanic and Atmospheric Administration; National Environmental Satellite, Data, and Information Service; National Climatic Data Center, Asheville, N.C.

Roback, J., 1982, Wages, Rents, and the Quality of Life, J. Political Economy, 90(6):1257-1278.

Thaler, R., and S. Rosen, 1976, The Value of Saving a Life: E'vidence from the Labor Market, in Household Production and Consumption, N.E. Terleckyj, ed., Columbia University Press, New York, pp. 265-298.

U.S. Department of Commerce, 1983, County and City Data Book, Bureau of the Census. 


\section{APPENDIX A}

\section{Study Site Samplo}

Sites included in the study sample are listed bolow. The tirst column lists the geographical unit code by which the area is designated in the PUMS B Sample. These codes are unique within states. The composition of the geographical data unit is shown in the second column, in which "multe" indicates a multicounty area and "subco" a subcounty unit. The next two columns give the County and City Data Book (CCDB) codes for the county and city considered to match the PUMS geographical unit most closely (U.S. Department of Commerce 1983). Asterisks in the last column indicate that the area given is for the county that includes the specified subcounty unit.

\begin{tabular}{|c|c|c|c|c|c|c|}
\hline $\begin{array}{l}\text { Puists } \\
\text { limeunt } \\
\text { loude }\end{array}$ & $\begin{array}{l}\text { PUMS } \\
\text { Arwa } \\
\text { Types }\end{array}$ & 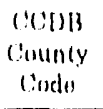 & $\begin{array}{l}\text { (1:1)13 } \\
\text { c:lity } \\
\text { cudis }\end{array}$ & (Ity & Bunnty & 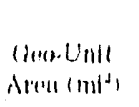 \\
\hline 111 & multe & $11 \%$ & 1195 & L,I'TYIIE ROK!K, AR & PUl's, AR & i, $11+i i 1$ \\
\hline 24 & cuunty & 21 & 11170 & KALAMAZ,OO, MII & BHKRRIGN, HI & 5.76 \\
\hline 11 & multc & 17 & $\mid r, 46$ & () (NALA, BL & Cl'I'RUS, lis & 2,767 \\
\hline त) & counity & 79 & 25,36 & SAN I,UIS (IBISIDO, CA & 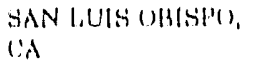 & in,it)H \\
\hline 16 & vounty & 76 & aritio & SYRAC:USE, NY & OSWVEOHO, NY & 45,4 \\
\hline is & sube: & litil & $3(1,3,4$ & YOKK, I'A & YOHK, I'A & !) \\
\hline 12 & yubou & 157 & 2420 & SACRAMHIV'TS, CA & SACRAMLIN'I], I'A & $97 ! *$ \\
\hline$\because 8$ & multe & 111 & 15,45 & () :ALA, Wh. & S'l, l.U(:IE, rl, & l, titil \\
\hline 14 & mulic & $|8|$ & (Bi) & VELVPYIR' NEWS, VA & SURRKY, VA & $: 1,173$ \\
\hline 40 & suber & $4 i$ & H(1) & HARKRLIBUR(h, I'A & MAUIHIN, I'A & iak \\
\hline 1 & multc & cin & 196 & BISIMAK(!K, NI) & $M(! t: A N, N)$ & :Iti, illi? \\
\hline$\therefore$ & mults & $i n$ & 511 & AHEYBNNWI, WY & PhA'TYH, WY & 28,1195 \\
\hline $2:$ & multe & $7 !$ & 25015 & THERE HAUTH, IN & Matillik, II, & 11,714 \\
\hline titi & multe: & $1+4 !$ & 2111 & AUSTIN, 'T'X & FAYEI"IS, 'T' & 4,11411 \\
\hline 5 & multe & 71 & yis & HUN'I'SVILLLE, ML & NA:KSON, M & $1, x+4 x$ \\
\hline 17 & imulte & tiil & {$[3+5 i 1$} & JOHNSTOOWN, PA & INIJIANA, PA & 1.176 \\
\hline 1117 & suboo & $7 i$ & 4476 & SAN DOBOH, CA & SAN IIE(IO), CA & $4,212=$ \\
\hline i) & multe & 17 & 111 & PLAOSTAFW, $A \%$ & NAVAO, A\% & $: 31,16 t i$ \\
\hline 10 & multe & $\mathrm{BF}$ & $: 10 \pi$ & 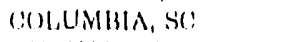 & SUM'IER, SC: & 4,401 \\
\hline 20 & inulte & $18 \pi$ & 7501 & 1)URHAM, VE: & WAKLREN, N(! & $\because 11465$ \\
\hline 324 & suben & int & 1715 & BLI'LABE'I'H, N.I & UNION, $\mathrm{NJ}$ & $\mid 11 i^{*}$ \\
\hline$k$ & city & 96 & 222011 & KANSIAS GI'TY, MO & MO:KSON, MO & ilti \\
\hline $3 i$ & multe & 017 & $37+45$ & SAN AN'TONIO, TX & BAVALA, TX & $|4, i|(n)$ \\
\hline 975 & multc & lis & +116 & STPUULBLNVILLE, OH & BELAHON'T, OH & 1,illik \\
\hline 01 & subes & $\mathrm{HI}$ & $86 i 5$ & GINCINNATI, OH & HAMII:TON, (NH & $412^{*}$ \\
\hline i) & multe & $|4 i|$ & $24 t i 5$ & TULSAs, OK & TULAiA, ok & a,7ti7 \\
\hline 2 & multe & $\mathrm{big}$ & 2690 & WAUSAU, WI & GINGOLIN, WVI & 4,767 \\
\hline 13 & cily & siil & 1280 & TACOMA, WA & PIAROE, WA & 48 \\
\hline$\because y$ & nubles & 2at & $64(1)$ & BROCIK'TON, MA & PI.YMOUNH, MA & birin* \\
\hline ytiti & sulien & 11 & 14811 & 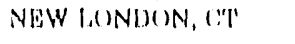 & NEW LONI)UN, (:I' & titits. \\
\hline$: 17$ & suleo & '4) & 75 & A'I'LAN'IIL: (!II'Y, N,I & (W:HAN, N.I & $\left|w_{1}\right|$ \\
\hline 21 & multe & 117 & ill 110 & ROK:HES'TER, NY & WAYNR, NY & 1,882 \\
\hline 34 & county & $21 !$ & $38: 111$ & S'l, CHARL,WS, MO) & IVARIRBN, MII & +125 \\
\hline $2 \pi$ & suber & $6 i i$ & 2515 & NIACIARA WALIAS, NY & NIALARILA, NY & risti* \\
\hline $2 t i$ & suben & 184 & : 1875 & STI l.ouls, Mo & S'l', LoUIS, & Filiti* \\
\hline
\end{tabular}




\begin{tabular}{|c|c|c|c|c|c|c|}
\hline $\begin{array}{l}\text { loums } \\
\text { cinement } \\
\text { roude }\end{array}$ & $\begin{array}{l}\text { PUMS } \\
\text { Ar'n } \\
\text { 'T'yp' }\end{array}$ & $\begin{array}{l}\text { ciciols } \\
\text { County } \\
\text { ciodo }\end{array}$ & $\begin{array}{l}\text { (1)il) } \\
\text { cilly } \\
\text { liclu }\end{array}$ & lifly & County & $\begin{array}{l}\text { (best Unit } \\
\text { Aren (mil) }\end{array}$ \\
\hline 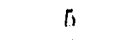 & vily & 1 & . 811 & $A I, 1 B N N Y, N Y$ & AIBANY, NY & 22 \\
\hline i) & subuen & 31 & isisan & 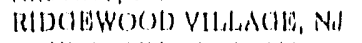 & ['ASSAIC, NI & $187^{*}$ \\
\hline 10 & subeu & 31 & 24001 & NEW BRUNSWICK, N.I & MIDDl.MSlax, $N_{1}$ & $31 H^{*}$ \\
\hline Wh & cotunty & IBiI & 38111 & $S^{\prime} T^{\prime}, \quad(H A R L A S, M O$ & a'T, (HAKL, ISS, MO & firs \\
\hline 111 & ulty & lis & 33() & THMIN, $\wedge 2$ & MAKICOPA, AZ & 38 \\
\hline 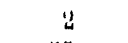 & Bullow & 1 & 16300 & NOKWALK, C'I & PAIRENLLLD, $(: ")^{\prime}$ & $1332 *$ \\
\hline 26 & toulinty & 81 & 215 & BHADBNI'ON, MI, & MANATDE, WI. & 747 \\
\hline 21 & multe & 127 & $2 r i 40$ & SAVANNAH, GA & III,YNN, GA & $!, 411 H_{1}$ \\
\hline 5 & wlty & 173 & 31140 & WIC:HI'IA, KS & SLDOWWLIK, KS & $|0|$ \\
\hline B & subeo & $\pi$ & $\$ 1760$ & P'OK'I'LAND, MID & ('UMBBSERLAND), Mli: & 876 \\
\hline lii & suben & i) & 11 & ANNAP(O)IS, MO & $\begin{array}{l}\text { MNNIS ARUNDLiL, } \\
\text { Wil) }\end{array}$ & $418^{*}$ \\
\hline isti & vily & l(tii) & 681 & IHE'TROOI'T, MII & WAYNH, WII & 166 \\
\hline 962 & wily & 137 & 1040 & DUL,U'IH, WN & $S^{\prime} l$ lotus, WN & 67 \\
\hline !y & subes & 169 & litoo & HUN'IINGITON BBAOH, IAA & ORANOH, CA & $748 *$ \\
\hline il & multe & 15 & 150 & A'I'LAN'I'A, OA & BAIR'OUW, GA & 2,2437 \\
\hline ilii & county & 21 & Enlail & WOHINSTOWN, PA & CAMIBIRIA, P'A & (t)\}l \\
\hline (i) & multe & li39) & B.b & WI. DORADO, AR & UNION, AR & A, 8 rinis \\
\hline 4 & multe & |iit) & 1abo & HUT'HHINSON, KS & $k l(\mathrm{H}, \mathrm{k} s$ & $3,4: 277$ \\
\hline il & multc & lail & :IHSE & BRIS, PA & WALKLWN, I'A & $1,84 \%$ \\
\hline litt & tounty & 245 & Bisiti & I'OK'T AR'IHUJ, 'I'X & MBPHRSON, T'X & $9: 17$ \\
\hline 19 & multc & 199 & 691 & HAMP'ION, VA & YOKK, VA & $4 ! 1$ \\
\hline 2 & anunty & 57 & 80 & BH,LLINUHAM, WA & SKAOI'I', WA & $1, \pi i n$ \\
\hline 442 & vity & 31 & 25001 & SUI'ERIOL, WI & DOUOHASS, WI & 39 \\
\hline$n 7$ & corunty & 167 & 42331 & 'TEXAS (III'Y, 'I'X & GALVASION, 'IX & :34!) \\
\hline 111 & sultico & 79 & 180 & BIRMINGIHAM, NL. & MEPHRSON, Al. & $1,119)^{*}$ \\
\hline ik & subeo & 25 & $\sqrt[440]{ }$ & BOS'I'ON, MA & SUPFOLK, WA & $57^{\circ}$ \\
\hline is & subes & $2 \pi$ & 2500 & L.ONC BRANGH, No] & MONMIOU'I'H, N.I & $472^{*}$ \\
\hline Iti & subeo & $|81|$ & 20120 & RAL Wil(HH, Ne: & WAKH, No! & $8 r .4 *$ \\
\hline 35 & cily & 119 & 480 & (:HARL,O'VIH, NC: & $\begin{array}{l}\text { MELKLENHURG, } \\
\text { No: }\end{array}$ & $\mid 411$ \\
\hline (!) & cuunty & .17 & iiit? & BULNSIVIILIL, MN & MAKOI'A, MN & 674 \\
\hline 8 & multc & 6 & 1080 & IRICHIANNI, WA & BBSN'ION, WI & 2,458 \\
\hline lit & mults: & 11 & !nor & (U) U.UMHBIA, SC: & BARNWEII, SC! & $\because, 857$ \\
\hline 7 & multe & $|2|$ & 1011 & IBl.AO'KSIBUIREI'I'UWN, VA & MUNRCHAGRY, VA & $1,|\sqrt{1}|$ \\
\hline :1 & county & 47 & $35 \sqrt{3}$ & FREDERIC:K, MOI & H(OWARI), MI) & $2 \pi 1$ \\
\hline lti & emunty & $10: 1$ & 6711 & BRUNSWIOK, OH & MEDINA, OH & 怡 \\
\hline lis & county & 94 & 720 & MEDWOKD, OR & JACKSON, OK & 2,787 \\
\hline 1 & multc & 57 & 226 & GORVALIAS, OKR & 'l'lli.AM()ok, ()K & $3,2,74$ \\
\hline 10 & county & 8í & $15 \times+5$ & ONA, WL & MARION, WL & $1,6 i l)$ \\
\hline lis & multc & [4i] & 26.10 & SAMINA, KS & U'VI'AWA, KS & 6,124 \\
\hline bis & city & $101 \mid$ & 7180 & PHILADOBLAHIA, PA & PHILADELIPHIA, PA & $133 i$ \\
\hline i & cily & il & 120 & DENVER, (CO & DENVGK, CO & 111 \\
\hline 1 & multe & 45 & 5155 & (IRANI) JUNE:IIION, (:O) & (BARFlGLI), (CO) & 14,216 \\
\hline 16 & erounty & 101 & 11185 & PUEBLO, CO & 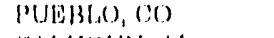 & 2,1777 \\
\hline 7 & county & 15 & 611 & ANNISION, AL & (IALHOUN, AL & bil \\
\hline 26 & multc & 165 & 25,05 & TWRIRE HAUTE, IN & VliIRMIII,ION, IN & 1,477 \\
\hline$x$ & multc: & 161 & 11611 & LEXINCTYN-WAYGT'R, KY & $M A U S S O N, K Y$ & 1,448 \\
\hline 6 & county & 26 & 261 & BALI'IMOIRE, MI) & HARLP(SRI), MD & $4+8$ \\
\hline 10 & multo & 56 & 610 & KENNEWICK, WA & UMA'I'IL,LA, OK & 111,2017 \\
\hline 7 & multe & 46 & 870 & SAL'T' LAKG CI'TY, U'T' & 'TOOSH, U', U' & 7,218 \\
\hline
\end{tabular}




\section{APPENDIX B}

\section{Documentation of PUMS Variable Modifications}

Many of the PUMS variables required modification or recoding to facilitate their use in regression analysis. Some PUMS data are released to the public in categorical form even though interval data are collected. Such information includes variables such as the house value and the year a structure was built. These variables were converted to approximate interval data by using the midpoints of the reported categories. Some variables were recoded so that the coding would correspond to the number of units of a feature, such as bedrooms. Others were recoded for use as dummy variables reflecting the presence or absence of one of a group of similar features.

The recoding applied to each modified variable and the associated definitions are provided in the two tables that follow. PUMS person-record variables are listed in Table B.1. and housing-record variables in Table B.2.

TABLE B.1 Person Record Variable Modifications

\begin{tabular}{|c|c|c|}
\hline Variable & New Coding & Definition \\
\hline $\mathrm{AGFF}$ & $\begin{array}{l}0 \\
1\end{array}$ & $\begin{array}{l}\text { Not applicable } \\
\text { Agriculture, forestry, and fisheries } \\
\text { (INDUSTRY CODES 10-31.) }\end{array}$ \\
\hline ANHRSWK & & HOURS79 $\times$ WEEKSW79 \\
\hline CONSTR & $\begin{array}{l}0 \\
1\end{array}$ & $\begin{array}{l}\text { Not applicable } \\
\text { Construction (INDUSTRY CODE 60) }\end{array}$ \\
\hline DISABIL1 & $\begin{array}{l}0 \\
1\end{array}$ & $\begin{array}{l}\text { No work disability } \\
\text { Work disability }\end{array}$ \\
\hline ENTERREC & $\begin{array}{l}0 \\
1\end{array}$ & $\begin{array}{l}\text { Not applicable } \\
\text { Entertainment and recreation services } \\
\text { (INDUSTRY CODES } 800-802 \text { ) }\end{array}$ \\
\hline EXPER & & Age minus 6 minus grade \\
\hline EXPER2 & & EXPER $\times$ EXPER \\
\hline FARMFISH & $\begin{array}{l}0 \\
1\end{array}$ & $\begin{array}{l}\text { Not applicable } \\
\text { Farming, forestry, and fishing } \\
\text { (OCCUPATION CODES } 473-499 \text { ) }\end{array}$ \\
\hline
\end{tabular}


TABLE B.1 (Cont'd)

\begin{tabular}{|c|c|c|}
\hline Variable & New Coding & Definition \\
\hline \multirow[t]{2}{*}{ FINIRE } & 0 & Not applicable \\
\hline & 1. & $\begin{array}{l}\text { Finarice, insurance, and real estate } \\
\text { (INDUSTRY CODES 700)-7:12) }\end{array}$ \\
\hline \multirow[t]{2}{*}{ FULLTIME } & 1 & HOURS $79 \geq 40$ \\
\hline & 0 & Otherwise \\
\hline \multirow[t]{23}{*}{ GRADE } & 0 & Never attended \\
\hline & 1 & Highest year was nursery school \\
\hline & 2 & Highest year was kindergarten \\
\hline & 3 & Highest year was first grade \\
\hline & 4 & Highest year was second grade \\
\hline & 5 & Third grade \\
\hline & 6 & Fourth grade \\
\hline & 7 & Fifth grade \\
\hline & 8 & Sixth grade \\
\hline & 9 & Seventh grade \\
\hline & 10 & Eighth grade \\
\hline & 11 & Ninth grade \\
\hline & 12 & Tenth grade \\
\hline & 13 & Eleventh grade \\
\hline & 14 & Twelfth grade \\
\hline & 15 & First year of college \\
\hline & 16 & Second year \\
\hline & 17 & Third year \\
\hline & 18 & Fourth year \\
\hline & 19 & Fitth year \\
\hline & 20 & Sixth year \\
\hline & 21 & Seventh year \\
\hline & 22 & Eighth year o: more \\
\hline HOURS79 & & $\begin{array}{l}\text { Usual number of hours worked per week } \\
\text { in } 1979(01-98)\end{array}$ \\
\hline INCOME 1 & & $\begin{array}{l}\text { Wage or salary income in } 1979 \text { : } \\
\text { income in dollars }(0005-74995) \text { at } \\
\text { midpoint of } \$ 10 \text { interval } \\
\text { (note: excludes category } \geq 75,000)\end{array}$ \\
\hline INCOME2 & & $\begin{array}{l}\text { Nonfarm self-employment income in } \\
1979 \text { : income in dollars }(00005-74995) \text { at } \\
\text { midpoint of } \$ 10 \text { interval } \\
\text { (note: excludes category } \geq 75,000)\end{array}$ \\
\hline
\end{tabular}


TABLE B.1 (Cont'd)

\begin{tabular}{|c|c|c|}
\hline Variable & New Coding & Detinition \\
\hline ISERVICE & $\begin{array}{l}0 \\
1\end{array}$ & $\begin{array}{l}\text { Not applicable } \\
\text { Business and repair services } \\
\text { (INDUSTRY CODES } 721.791 \text { ) }\end{array}$ \\
\hline MARITAL & $\begin{array}{l}0 \\
1\end{array}$ & $\begin{array}{l}\text { Widowed, divorced, separated, single, or not } \\
\text { applicable (under } 15 \text { years old) } \\
\text { Married }\end{array}$ \\
\hline MGTPROF & $\begin{array}{l}0 \\
1\end{array}$ & $\begin{array}{l}\text { Not applicable } \\
\text { Managerial and professional specialties } \\
\text { (OCCUPATION CODES } \geq 3 \text { and } \leq 199\end{array}$ \\
\hline MINING & $\begin{array}{l}0 \\
1\end{array}$ & $\begin{array}{l}\text { Not applicable } \\
\text { INDUSTRY CODES } 40-50\end{array}$ \\
\hline OPERLABR & $\begin{array}{l}0 \\
1\end{array}$ & $\begin{array}{l}\text { Not applicable } \\
\text { Operators, fabricators, and laborers } \\
\text { (OCCUPATION CODES 703-889) }\end{array}$ \\
\hline PADMIN & $\begin{array}{l}0 \\
1\end{array}$ & $\begin{array}{l}\text { Not applicable } \\
\text { Public administration } \\
\text { (INDUSTRY CODES } 900-932 \text { ) }\end{array}$ \\
\hline PRODREPR & $\begin{array}{l}0 \\
1\end{array}$ & $\begin{array}{l}\text { Not applicable } \\
\text { Precision production, craft, and repair } \\
\text { (OCCUPATION CODES 50:3-699) }\end{array}$ \\
\hline PROFSERV & $\begin{array}{l}0 \\
1\end{array}$ & $\begin{array}{l}\text { Not applicable } \\
\text { Professional and related services } \\
\text { (INDUSTRY CODES } 812-892 \text { ) }\end{array}$ \\
\hline S.A.LES & $\begin{array}{l}0 \\
1\end{array}$ & $\begin{array}{l}\text { Not applicable } \\
\text { Wholesale and retail trade } \\
\text { (INDUSTRY CODES } 500-691 \text { ) }\end{array}$ \\
\hline SERVICE & $\begin{array}{l}0 \\
1\end{array}$ & $\begin{array}{l}\text { Not applicable } \\
\text { OCCUPATION CODES } 403-469\end{array}$ \\
\hline SEX & $\begin{array}{l}1 \\
0\end{array}$ & $\begin{array}{l}\text { Female } \\
\text { Male }\end{array}$ \\
\hline SEXMAR & & SEX $\times$ MARITAL \\
\hline TECHSALE & $\begin{array}{l}0 \\
1\end{array}$ & $\begin{array}{l}\text { Not applicab!e } \\
\text { Technical, sales, and administrative support } \\
\text { (OCCUPATION CODES 203-389) }\end{array}$ \\
\hline
\end{tabular}


TABLE B.1 (Cont'd)

\begin{tabular}{lcl}
\hline Variable & New Coding & Definition \\
\hline TOTERINC & & INCOME1 + INCOME2 if WEEKSW79 \pm 0 \\
TRANSCU & 0 & $\begin{array}{l}\text { Not applicable } \\
\text { Transportation, communications, and other } \\
\text { public utilities (INDUSTRY CODES 400-472) }\end{array}$ \\
VETERAN1 & 1 & $\begin{array}{l}\text { Veteran of the armed forces } \\
\text { Not a veteran }\end{array}$ \\
WEEKSW79 & 1 & Weeks worked in 1979 \\
WHITE & 0 & RACE $=1$ \\
& 1 & Nonwhite \\
\hline
\end{tabular}


TABLE B.2 Housing Record Variable Modifications

\begin{tabular}{|c|c|c|}
\hline Variable & New Coding & Detinition \\
\hline \multirow[t]{2}{*}{ ACREGT1 } & 1 & $\begin{array}{l}\text { If } A C R E A G E 2=2, \text { one to nine acres } \\
\text { If } A C R E A G E 2=3,10 \text { or more acres }\end{array}$ \\
\hline & 0 & Otherwise \\
\hline \multirow[t]{2}{*}{ AREA1 } & 1 & If AREATYPE = 1 (central city of SMSA) \\
\hline & 0 & Utherwise \\
\hline \multirow[t]{2}{*}{ AREAL } & 1 & If AREATYPE $=5$ (outside SMSA) \\
\hline & () & Otherwise \\
\hline \multirow[t]{4}{*}{ BATHROOM } & 0 & No bathroom or only a half bath \\
\hline & 1 & One complete bathroom \\
\hline & 2 & One complete bathroom plus half bath(s) \\
\hline & 3 & Two or more complete baths \\
\hline \multirow[t]{6}{*}{ BEDROOMS } & 0 & None \\
\hline & 1 & One bedroom \\
\hline & 2 & Two bedrooms \\
\hline & 3 & Three bedrooms \\
\hline & 4 & Four bedrooms \\
\hline & 5 & Five or more bedrooms \\
\hline \multirow{7}{*}{$\begin{array}{l}\text { BLDAGE } \\
\text { (previously } \\
\text { named YRBUILT) }\end{array}$} & 0.6 & 1979 to March 1980 \\
\hline & 3.3 & 1975 to 1978 \\
\hline & 7.75 & 1970 to 1974 \\
\hline & 15.3 & 1960 to 1969 \\
\hline & 25.3 & 1950 to 1959 \\
\hline & 35.3 & 1940 to 1949 \\
\hline & 60 & 1939 or earlier \\
\hline \multirow[t]{2}{*}{ CENTAIR } & 1 & Central air-conditioning system \\
\hline & 0 & Otherwise \\
\hline \multirow[t]{2}{*}{ CONDO } & 0 & Not a condominium unit \\
\hline & 1 & Condominium unit \\
\hline \multirow[t]{2}{*}{$\begin{array}{l}\text { DETACHED (previously } \\
\text { included in UNITS1) }\end{array}$} & 1 & $\begin{array}{l}\text { One-family house detached from any other } \\
\text { house }\end{array}$ \\
\hline & 0 & $\begin{array}{l}\text { One-family house attached to one or more } \\
\text { houses }\end{array}$ \\
\hline \multirow[t]{4}{*}{ HEATING } & 0 & Floor, wall, or pipeless furnace \\
\hline & & Room heaters with flue \\
\hline & & Room heaters without flue \\
\hline & & $\begin{array}{l}\text { Fireplaces, stoves, or portable room heaters } \\
\text { None }\end{array}$ \\
\hline
\end{tabular}


TABLE B.2 (Cont'd)

\begin{tabular}{|c|c|c|}
\hline Variable & New Coding & Definition \\
\hline HEATING (Cont'd) & 1 & $\begin{array}{l}\text { Steam or hot water system } \\
\text { Central warm-air turnace } \\
\text { Electric heat pump } \\
\text { Other built-in electric urits }\end{array}$ \\
\hline OT'HRROOM & & Rooms minus bedrooms \\
\hline RENT2 & & Gross rent in dollars (001-998) \\
\hline ROOMS & $\begin{array}{l}1 \\
2 \\
3 \\
4 \\
5 \\
6 \\
7 \\
8 \\
9\end{array}$ & $\begin{array}{l}\text { One room } \\
\text { Two rooms } \\
\text { Three rooms } \\
\text { Four rooms } \\
\text { Five rooms } \\
\text { Six rooms } \\
\text { Seven rooms } \\
\text { Eight rooms } \\
\text { Nine or more rooms }\end{array}$ \\
\hline SEWAGE & $\begin{array}{l}1 \\
0\end{array}$ & $\begin{array}{l}\text { Public sewer } \\
\text { Otherwise }\end{array}$ \\
\hline UNITS1 & $\begin{array}{l}1 \\
\\
2 \\
3.5 \\
7 \\
14.5 \\
34.5 \\
70\end{array}$ & $\begin{array}{l}\text { One-family house attached to one or more } \\
\text { houses } \\
\text { Building for } 2 \text { families } \\
\text { Building for } 3 \text { or } 4 \text { families } \\
\text { Building for } 5 \text { to } 9 \text { families } \\
\text { Building for } 10 \text { to } 19 \text { families } \\
\text { Building for } 20 \text { to } 49 \text { families } \\
\text { Building for } 50 \text { or more families }\end{array}$ \\
\hline VALUE & $\begin{array}{l}05 \\
13 \\
16 \\
19 \\
21 \\
24 \\
26 \\
29 \\
33 \\
38 \\
43 \\
48 \\
53 \\
58 \\
63\end{array}$ & $\begin{array}{l}\text { Less than } \$ 10,000 \\
\$ 10,000 \text { to } \$ 14,999 \\
\$ 15,000 \text { to } \$ 17,499 \\
\$ 17,500 \text { to } \$ 19,999 \\
\$ 20,000 \text { to } \$ 22,499 \\
\$ 22,500 \text { to } \$ 24,999 \\
\$ 25,000 \text { to } \$ 27,499 \\
\$ 27,500 \text { to } \$ 29,999 \\
\$ 30,000 \text { to } \$ 34,999 \\
\$ 35,000 \text { to } \$ 39,999 \\
\$ 40,000 \text { to } \$ 44,999 \\
\$ 45,000 \text { to } \$ 49,999 \\
\$ 50,000 \text { to } \$ 54,999 \\
\$ 55,000 \text { to } \$ 59,999 \\
\$ 60,000 \text { to } \$ 64,999\end{array}$ \\
\hline
\end{tabular}


TABLE B.2 (Cont'd)

\begin{tabular}{rrl}
\hline Variable & New Coding & \multicolumn{1}{c}{ Definition } \\
\hline VALUE (Cont'd) & 68 & $\$ 65,000$ to $\$ 69,999$ \\
& 73 & $\$ 70,000$ to $\$ 74,999$ \\
78 & $\$ 75,000$ to $\$ 79,999$ \\
& 85 & $\$ 80,000$ to $\$ 89,999$ \\
95 & $\$ 90,000$ to $\$ 99,999$ \\
& 113 & $\$ 100,000$ to $\$ 124,999$ \\
138 & $\$ 125,000$ to $\$ 149,999$ \\
175 & $\$ 150,000$ to $\$ 199,999$ \\
& 200 & $\$ 500,000$ or more \\
& 1 & Public system or private company \\
WATER & 0 & Otherwise \\
& & \\
YRMOVED & 1 & 1979 to March 1980 \\
& 3 & 1975 to 1978 \\
& 1970 to 1974 \\
& 1.5 & 1960 to 1969 \\
& 25 & 1950 to 1959 \\
& 50 & 1949 or earlier (endpoint 1900 ) \\
\hline
\end{tabular}




\section{APPENDLX C}

County and City Data Book Variables

\begin{tabular}{|c|c|}
\hline Name & Definition \\
\hline \multicolumn{2}{|l|}{ Variable: } \\
\hline COOLDAYS & Cooling-degree-days \\
\hline CITYAREA & City area $\left(\mathrm{mi}^{2}\right)$ \\
\hline CNTYAREA & County land area $\left(\mathrm{mi}^{2}\right)$ \\
\hline COLLEGE & Persons 25 and older with 16 or more years of education \\
\hline CRIMES & $\begin{array}{l}\text { Murder and nonnegligent manslaughter, forcible rape, robbery, } \\
\text { and aggravated assult per } 100,000 \text { people }\end{array}$ \\
\hline FAMIPOVTY & Total families below the poverty level \\
\hline FARMLAND & Acreage in farms $(1,000 \mathrm{~s})$ \\
\hline GENREVNU & Local government general revenue $(\$ 1,000$ s) \\
\hline GOVSPEND & Local government expenditure per capita \\
\hline HEATDAYS & Heating-degree-days \\
\hline HISCHOOL & Persons 25 and older with 12 or more years of education \\
\hline HMEDVAL & Median value of owner-occupied housing units \\
\hline HOSPITAL & Hospital beds per 100,000 people \\
\hline INCPERCP & Money income per capita \\
\hline JANTEMP & Average mean daily January temperature ( $\mathrm{F}$ ) \\
\hline JUL,YTEMP & Average mean daily July temperature $\left({ }^{\circ} \mathrm{F}\right)$ \\
\hline MEDHSINC & Median housolvold money income \\
\hline PCTPOVTY & Percentage of families below poverty level \\
\hline PUNEMP & Percentage of total labor force unemployed \\
\hline PCTWHITE & Percentage white population \\
\hline POPDENS & Population per square mile \\
\hline POPOVR25 & Population over 25 years old \\
\hline RMEDVAL & Median value of renter-occupied housing units \\
\hline TAXES & Total local government taxes $(\$ 1,000 \mathrm{~s})$ \\
\hline TOTPOP70 & Total population in 1970 \\
\hline TOTPOP80 & Total population in 1980 \\
\hline UNEMPLY & Total persons unemployed \\
\hline VACANCY & Percentage of year-round housing units vacant \\
\hline \multicolumn{2}{|c|}{ Calculated variable: } \\
\hline PCTHISCL & $\begin{array}{l}\text { Percentage of population older than } 25 \text { with } 12 \text { or more years of } \\
\text { education (HISCHOOL/POPOVR25) }\end{array}$ \\
\hline PCTCOLG & $\begin{array}{l}\text { Percentage of population older than } 25 \text { with } 16 \text { or more years of } \\
\text { education (COLLEGE/POPOVR25) }\end{array}$ \\
\hline POPCHNG & $\begin{array}{l}\text { Percentage county population change, } 1970-1980 \\
\text { ([TOTPOP80 - TOTPOP70VTOTPOP70) }\end{array}$ \\
\hline TAXPCAP & Local government taxes per capita (TAXES/TOTPOPSO) \\
\hline TEMPDIFF & Annual range of mean temperatures (JULYTEMP - JANTEMP) \\
\hline
\end{tabular}




\section{APPENDIX D}

\section{Facility Information Sources}

\section{Nuclear Generators}

Bergmann, P.A., 1982, Socioeconomic Impacts of Nuclear Generating Stations: Crystal. River Unit 3 Case Study, NUREG/CR-2749, U.S. Nuclear Regulatory Commission, Vol. 3, July.

Bergmann, P.A., 1982, Socioeconomic Impacts of Nuclear Generating Stations: Rancho Seco Case Study, NUREG/CR-2749, U.S. Nuclear Regulatory Commission, Vol. 9, July.

Branch, K, 1982, Socioeconomic Impacts of Nuclear Generating Stations: D.C. Cook Case Study, NUREG/CR-2749, U.S. Nuclear Regulatory Commission, Vol. 4, July.

Branch, K., R. Meale, and R. Cochran, 1982, Socioeconomic Impacts of Nuclear Generating Stations: Nine Mile Point and Fitzpatrick Case Study, NUREG/CR-2749, U.S. Nuclear Regulatory Commission, Vol. 6, July.

Edison Electric Institute, 1981, Power Directory, Washington, D.C.

Flynn, C., 1982, Socioeconomic Impacts of Nuclear Generating Stations: Three Mile Island Case Study, NUREG/CR-2749, U.S. Nuclear Regulatory Commission, Vol. 12, July.

Flynn, J., 1982, Socioeconomic Impacts of Nuclear Generating Stations: Surry Case Study, NUREG/CR-2749, U.S. Nuclear. Regulatory Commission, Vol. 11, July.

Gamble, H.B., R.H. Downing, and O.H. Sauerlender, 1979, Effects of Nuclear Pouer Plants on Community Grouth and Residential Yalues, NUREG/CR-0454, I.S. Nuclear Regulatory Commission.

Metz, W., ed., 1983, Population and Land Use Change in the Vicinity of Operating Nuclear Power Stations - An Anthology, Brookhaven National Laboratory, Long Island, N.Y.

Pijawka, K.D., 1982, Socioeconomic Impacts of Nuclear Generating Stations: Arkansas Nuclear One Station Case Study, NUREG/CR-2749, U.S. Nuclear Regulatory Commission, Vol. 1, July.

Pijawka, K.D., 1982, Socioeconomic Impacts of Nuclear Generating Stations: Peach Bottom Case Study, NUREG/CR-2749, U.S. Nuclear Regulatory Commission, Vol. 8, July.

Pijawka, K.D., and G. Yaquinto, 1982, Socioeconomic Impacts of Nuclear Generating Stations: Diablo Canyon Case Studv, NUREG/CR-2749, U.S. Nuclear Regulatory Commission, Vol. 5, July. 
Weisiger, M.L., and K.D. Pijawka, 1982, Socioeconomic Impacts of Nuclear Gencrating Stations: St. Lucie Case Study, NUREG/CR-2749, U.S. Nuclear Regulatory Commission, Vol, 10, July.

\section{Coal Power Plants}

Denver Research Institute, Industrial Economics Division, 1982, Socioeconomic Impacts of Power Plants, Final Report, Denver, Colo., Feb.

\section{Oil and Gas Power Plants}

Electrical World, 1986, Directory of Electric Utilities, 95th Ed, McGraw-Hill, New York.

U.S. Deparment of Energy, Energy Information Administration, 1984, Thermal. Electric Plant Construction Cost and Annual Production Expenses, 1981.

\section{CHEMDMIL}

Rouse, L.E., 1988, The Disposition of the: Current Stockpile of Chemical Munitions and Agents, Military Law Review, 121:17-23, Summer.

\section{Hazardous Waste}

Congress of the United States, Office of Technology Assessment, 1988, Are We Cleaning Up? 10 Superfund Case Studies, OTA-ITE-362.

Morell, D., and C. Magorian, 1982, Siting Hazardous Waste Facilities: Loca! Opposition and the Myth of Preemption, Ballinger Publishing Company, Cambridge, Mass.

U.S. Environmental Protection Agency, Office of Water and Waste Management, 1979, Siting of Hazardous Waste Management Facilities and Public Opposition. SW-809, prepared by Centaur Associates, Washington, D.C., Nov.

U.S. Environmental Protection Agency, 1990, Nationai Priorities List for Uncontrolled Hazardous' Waste Sites; Final Rule, Code of Federal Regulations, 40 CFR Part 300, March 14.

U.S. General Accounting Office, 1983, Siting of Hazardous Waste. Landfills and Their Correlation with Racial and Economic Status of Surrounding Communities, Washington, D.C., June.

U.S. Nuclear Regulatory Commission. Office of Nuclear Material Safety and Safeguards, 1983, Final Environmental Statement Related to the Decommissioning of the Rare Earth Facility, West Chicago, Illinois, May. 


\section{Refineries}

American Business Directories, 1988, U.S. Manufacturers Directory, 1988-89 Ed, Omaha, Neb.

Oil and Gas Journal Data Book, 1990, Penwell Publishing, Tulsa, Okla.

\section{FUSRAP}

U.S. Department of Energy, 1991, Environmental Restoration and Waste Management, FineYear Plan, Fiscal Years 1993-1997, FYP DOE/S-(1089P, Aug.

\section{LNG Storage}

Institute of Cras 'T'echnology, 1989, Annual Statistical Report, Chicago, Ill.

\section{Control Sites}

Electrical World, 1986, Directory of Electric Utilities, 95th Ed., McGraw-Hill, New York. Legislative Commission on Toxic Substances and Hazardous Wastes, 1987, Hazardous Waste Facility Siting: A National Survey', June. 

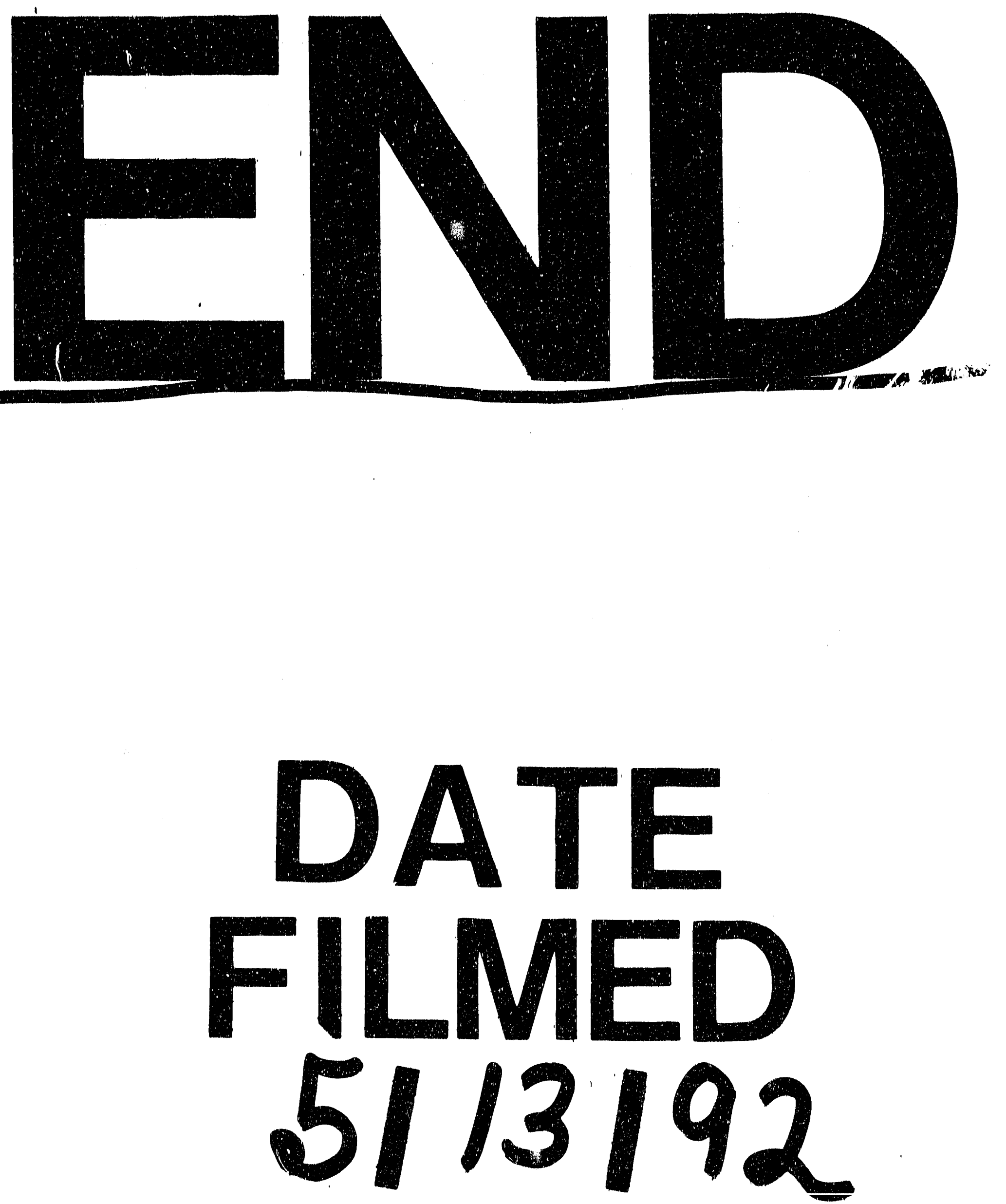


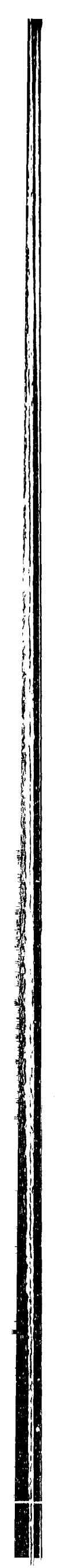

